\title{
Does the Gender of Directors Matter?
}

\author{
Miriam Schwartz-Ziv ${ }^{1}$
}

December 4, 2012

\begin{abstract}
How does gender-balance affect the working of boards of directors? I examine boards that have been required for two decades to be relatively gender-balanced: boards of business companies in which the Israeli government holds a substantial equity interest. I construct a novel database based on the detailed minutes of 402 board- and board-committee meetings of eleven such companies. I find that boards that had critical masses of at least three directors of each gender in attendance, and particularly of three women, were approximately twice as likely both to request further information and to take an initiative, compared to boards that did not have such critical masses. A 2SLS model confirms these results. Consistent with these findings, the ROE and net profit margin of these type of companies is significantly larger in companies that have at least three women directors. In addition, boards that included a critical mass of women directors were more likely to experience CEO turnover when firm performance was weak. At the level of the individual directors, both men and women directors were more active when at least three women directors were in attendance.
\end{abstract}

\footnotetext{
1 Harvard University and Northeastern University. E-mail: miriam.schwartz@mail.huji.ac.il. See papers.ssrn.com/sol3/papers.cfm?abstract_id=1868033 for the latest version. I am deeply grateful to Eugene Kandel and Michael Weisbach (the co-advisors of my Hebrew University doctoral dissertation, upon which this paper is based) for their continuing guidance and support. In addition, I thank the employees of the Government Companies Authority of Israel, who allowed me to conduct this research; the companies studied, which kindly provided me with private and sensitive data; and the following people who shared with me their thoughts and gave advice at different stages of the preparation of this paper: participants in doctoral finance seminars at Harvard, MIT, and Brandeis University, and in seminars at the Mossavar-Rahmani Center for Business \& Government at Harvard Kennedy School, the Program on Corporate Governance at Harvard Law School, Simmons College, the Women and Public Policy Program at Harvard Kennedy School, the Political Economy Workshop at Harvard and Renée Adams, Bo Becker, Shai Bernstein, Iris Bohnet, Constantine Boussalis, Travis Coan, Lauren Cohen, Alon Eizenberg, Ronel Elul, Olubunmi Faleye, Dirk Jenter, Paul Gompers, Robin Greenwood, Boris Groysberg, Assaf Hamdani, Victoria Ivashina, Jasmin Joecks, Natalia Karelaia, Saul Lach, Lubomir Litov, Evgeny Lyandres, Nadya Malenko, Amalia Miller, Johanna Mollerstrom, Udi Nisan, Antoinette Schoar, Elis Sisli, Stanislav Sokolinski, Daniel Schwartz, Schraga Schwartz, Lucy White, and Tammar Zilber. I also thank the Program on Corporate Governance at Harvard Law School and the Women and Public Policy Program at Harvard Kennedy School for hosting me as a fellow while working on the paper. Finally, I thank the Israeli Ministry of Science and Technology and the Hebrew University's School of Business Administration for financial support.
} 


\section{Introduction}

There has been a longstanding interest in the makeup of boards of directors, both in the academic literature and in the popular press. Lately, board diversity, and particularly the gender of directors has been a topic of much attention, since there is a recent movement to impose diversity requirements on boards. In the United States, the Securities Exchange Commission requires that companies disclose whether they have a diversity policy, and how it applies to board recruitment practices (Regulation S-K, Item 407(c)). Several European countries - including Norway, France, Spain, and Italy, have already legislated laws enforcing gender quotas. Furthermore, Dr. Viviane Reding, the Vice President of the European Commission, has recently attempted, but not succeeded, to promote legislation enforcing gender quotas in all European countries (Wall Street Journal, Oct. 23, 2012).

Nevertheless, it remains unclear whether gender diversity has a meaningful impact upon board and firm performance, and how such impact might be measured. The common empirical strategy for examining the associations between the (gender) composition of boards and board performance is analyzing the associations between the former and financial performance. Rhode and Packel (2010) survey more than two dozen studies examining the association between the gender composition of boards and financial performance, and conclude that no robust and consistent relation has been documented between these two variables. Furthermore, as emphasized by Hermalin and Weisbach (2003), board composition is jointly determined with firm performance, so it is problematic to draw inferences from the associations between financial performance and board composition. Hermalin and Weisbach argue that rather than looking at the impact of boards on a firm's overall financial performance, it is better to understand the impact of board composition by considering how it affects the actions the board or the firm takes, given the board composition at the time an action is taken.

Most "action-based" studies which examine the actions boards take, rely on publicly available information, and consequently usually study only a narrow set of observable actions. Such actions include the decision to replace a CEO, to adopt a poison pill, or to acquire another company. However, boards take many actions in each meeting that are unobservable to outsiders, but are recorded in the board minutes. In this paper I analyze detailed minutes, which are quasi-transcripts, of the board and board-committee meetings of eleven companies in which the Israeli government holds a substantial equity interest 
(Government Business Companies, or GBCs,). These companies are for-profit companies and are explicitly required by law to maximize their profits. ${ }^{2}$ For each company, minutes for one year in the period 2007-2009 are examined - altogether 155 board meetings and 247 meetings of board-committees. These minutes document the details of the meetings, including the statements made by every participant in each meeting. Altogether, 2,459 issues were discussed in these meetings. ${ }^{3}$

I use this database to evaluate the extent to which the gender of a board affects its actions. These data are ideal for understanding the effect of gender on board dynamics for at least three reasons. First, unlike studies based on publicly available information, I can observe the actions of directors at their meetings, most of which are unobservable to outsiders. ${ }^{4}$ Second, because I know the attendance at every board meeting and which actions were taken at each one, I can control for firm-level characteristics by using within-firm variation across meetings. Third, these companies have boards that are relatively genderbalanced, containing roughly $37 \%$ women, and have included a large proportion of women for almost two decades. This diversity is different from most boards of directors, since with a few exceptions such as the Scandinavian countries, most countries' boards, including those in the United States, include on average only 5\%-16\% women directors (Catalyst, 2012). Such boards are ill-suited to study the effects of diversity beyond very low levels of female participation.

As a point of departure I take the hypothesis offered by Shrader et al. (1997), Rosener (1995), and Kramer et al. (2007): In board meetings, a critical mass of three women directors (which constitutes approximately a third of the board) will catalyze board activeness/performance. This argument is based on the critical-mass theory introduced by Kanter (1977), who argues that only when women comprise at least $35 \%$ of a team, thereby creating more gender-balanced teams, gender diversity will enhance team performance. I examine empirically whether the existence of a critical mass of three women directors, and also one of three men directors, indeed catalyzes board activity, and whether it is related to financial performance. Although the critical mass argument emphasizes the importance of a critical mass of women, I choose to address the impact of a critical mass of both genders, to

\footnotetext{
${ }^{2}$ In addition, as will be detailed, the characteristics of men and women GBC directors are similar to those of directors in other countries.

${ }^{3}$ See Schwartz-Ziv and Weisbach (2012) on the board dynamics documented in this database.

${ }^{4}$ Most likely, it would not be possible to observe the actions each director took on the basis of minutes of American companies, for the latter rarely detail the board's discussions.
} 
understand to the extent possible given the variation in the data, whether the critical-mass effect applies to both genders.

I capture board activeness using two variables: based on the minutes-data, I document for each of the 2459 issues discussed whether the board (1) requested to receive further information or an update and (2) whether it took an initiative, such as proposing which action should be taken. These two actions document the extent boards are involved in monitoring on the one hand (as measured by the first variable), and being involved in managing the company on the other (as measured by the second variable). First, I examine how the gender composition of the directors in attendance impacts upon the likelihood that a board will take each of these actions. The empirical results indicate that boards are most active when they are relatively gender-balanced - when at least three men and three women directors are in attendance, a situation I term a "dual-critical mass". Boards with such a dual-critical mass were found, in comparison to boards without one, to be approximately twice as likely to request further information or an update, and also to take an initiative. These results are driven more strongly by the presence of a critical mass of women directors.

To address the possible concern that non-random attendance is driving these results (i.e., that one of the genders is likely to attend meetings especially when high/low activeness is expected to be required), I use instrumental variables (IVs) to assess the likelihood that men and women directors attend a particular meeting in which a particular issue is discussed. Specifically, I use two IVs that document the number of women directors, and the number of men directors that had at least one board-committee committee scheduled on the same day a particular board meeting took place, at which a particular issue was discussed. These instruments exploit the reality that GBC directors have a higher incentive to attend meetings on days when they have additional committees, for the compensation GBC directors receive depends only on the number of meetings they attend. Furthermore, the meetings are in the vast majority of cases scheduled months in advance, while the agenda for each meeting is set one to three weeks prior to each meeting. Hence, the IVs have no direct effect on the likelihood that boards will take an action (i.e., request to receive an update or take an initiative). When using these IVs, the finding that boards are most active when they are gender-balanced, holds.

The natural question that arises from these findings is: How does the gendercomposition of boards relate to firm performance? To address this question I examine the relation between the gender composition of the GBC boards and financial performance. I examine a panel data of the universe of the 34 GBCs for the years 1997-2009, which once 
again, pertains to boards that are more gender-balanced than most other boards. Consistent with the abovementioned findings pertaining to women directors, ROE and net profit margins are found to be significantly larger in companies that have at least three women directors. Taken together with the abovementioned findings pertaining to the work of boards below the surface, which document a causal relation in the same direction, the findings pertaining to financial performance seem to indicate that gender diversity leads to enhanced financial performance (rather than it being only associated with it).

The abovementioned findings documenting the impact of a critical mass of a certain gender raise the question whether the patterns documented also prevail on the level of the individual woman and/ or man director. I examine how critical masses of men and women directors impact upon the likelihood that an individual man or woman director take an action (i.e., that he or she request an update or take an initiative). The likelihood that each gender of directors take an action is adjusted using the Horvitz-Thompson estimator. This estimator adjusts for the fact that usually women directors constituted a smaller fraction of all attending directors, and therefore, all else equal, the likelihood that an action is taken by a woman director is smaller than the likelihood that an action is taken by a man director. I find that on the level of the individual director, the presence of a critical mass of women directors increases the likelihood that both a man and a woman director take an action.

To understand whether the gender of directors plays a role in times the board is particularly needed, I examine periods during which companies are between CEOs, when they are in the process of replacing their CEO ("gap periods"). First, I examine the impact of the gender of directors above the surface, i.e., on the likelihood that CEO turnover occur. I analyze the panel data-set of 34 GBCs for the years 1997-2009. I find that firms with weak financial performance, which also have boards that include a critical mass of at least three women directors, are more likely to replace their CEOs. I then examine the impact of gender beneath the surface during gap periods, using the minutes-data. Once again, during gap periods boards are found to be particularly active if a critical mass of women directors is in attendance. In addition, the women directors are found to be particularly active during these gap periods.

I also explore whether women and men directors have propensities to be active concerning different types of tasks, specifically, concerning issues that tend to be supervisory as opposed to managerial issues. Because both men and women directors may not be appointed to the (type of) committees they request to be appointed, I examine separately the actions taken by each gender of directors in board-committee meetings versus board 
meetings. Both in board-committee meetings and in board meetings, relative to men directors, women directors were found to take more frequently actions pertaining to supervisory issues. The flip side of this finding is that men directors were significantly more likely to take actions pertaining to managerial issues.

Last, I examine if gender plays a role with respect to communication. I find that in board-committee meetings, the larger the percentage of women directors in attendance, the longer the discussions - a finding which implies that women directors increase communication, particularly in small teams.

Taken together, the findings of this study stress that gender-balanced boards are more active, and have a more diverse set of skills.

\section{The Impact of the Gender of Directors - What Do We Know?}

The most common approach in finance literature to generating an understanding of the impact of board composition on board performance, and ultimately on firm performance, is to examine the association between board composition and firm performance. However this approach is plagued with endogeneity, ${ }^{5}$ and has also failed to document consistent findings on the relationship between gender and financial performance. Rhode and Packel (2010), who provide a comprehensive survey of more than two dozen empirical studies that examine that question, conclude that such a relationship has not been convincingly established. ${ }^{6}$

Specifically, some studies find a positive association between the percentage of women directors and financial performance (e.g. Carter et al., 2003; Erhardt et al., 2003; and Farrel and Hersh, 2005), some find no relationship (e.g., Shrader et. al, 1997), and others have documented a negative one (e.g., Adams and Ferreira, 2009). Thus, studies of this type have not provided a conclusive answer as to whether increasing the number/ proportion of women directors is beneficial. However, all the studies just mentioned, and most other studies of this kind, examine boards that had on average less than $10 \%$ women directors. These nongender-balanced boards may not reflect the impact of gender in more gender-balanced boards.

\footnotetext{
${ }^{5}$ For example, if a positive association between the fraction of women directors and firm performance is documented, this could be interpreted as an indication that women enhance firm performance. However, it is also possible to argue that firms with strong firm performance have the luxury of being able to appoint more women directors (who may be less competent), so as to avoid public pressure to hire women directors, as Facebook recently faced, which led to the appointment of Sheryl Sandberg (Bloomberg, 2012).

${ }^{6}$ Similarly, also with respect to insiders versus outsiders, as Hermalin and Weisbach (2003) and Dalton et al. (1998) stress, studies have not documented a significant and consistent relationship between the proportion of outside directors and firm performance.
} 
Matsa and Miller (2011) and Ahern and Dittmar (2012) investigate how a change in Norwegian legislation, which required that beginning in 2007 at least $40 \%$ of the directors of Norwegian firms be women, impacted upon the performance of these firms. Matsa and Miller (2011) found a decrease in their profitability, and Ahern and Dittmar (2012) found, similarly, a decrease in their value. However, these studies examine boards that became genderbalanced at one fell swoop, immediately upon the change in legislation. Consequently, they do not study a steady state in which the demand and supply for women directors is in equilibrium. For as these studies demonstrate, the sudden demand for female directors had a simultaneous side-effect: the new female board-members appointed were younger and less experienced than the men and the women directors that were already serving on the boards of the Norwegian firms. Hence, the decline in firm performance was not necessarily caused by the rise in the percentage of women directors; rather, it may well have been caused by the rise in the percentage of young and inexperienced directors. Accordingly, research on "steady state" boards that have not experienced a recent market shock in the demand and supply of the directors of the minority gender may be beneficial.

Boards are teams that conduct different types of complex tasks that require coordination among the team members. For this reason, the literature on the impact of gender on the working of teams may shed light on the impact of the gender of directors on their team work. Bear and Woolley (2011) review the literature on the impact of the gender of team members, and conclude that "recent evidence strongly suggests that team collaboration is greatly improved by the presence of women in the group". In an experiment conducted by Woolley et al. (2010), gender-balanced teams outperformed non-gender-balanced teams in complex tasks they were required to perform. Hoogendoorn et al. (2011) and Apesteguia et al. (2011) conducted experiments in which teams comprised of different proportions of male and female MBA students compete in maximizing their team's/ "firm's" wealth. Both studies find evidence implying that gender balanced-teams outperform non-gender-balanced teams. Similarly, Allmendinger and Hackman (1995) examine how the gender of the players in orchestras affected their functioning. They find that when women comprise roughly at least a third the orchestra, both men and women players were more satisfied with the orchestra's functioning.

Indeed, Kanter (1977), who introduced the critical mass theory, argues that in skewed groups, in which women comprise only a marginal fraction of a team, they will only serve as "tokens". According to Kanter, this means that women are treated as female representatives rather than individuals, which hinders the ability of women to perform 
optimally. Following Kanter, with respect to boards, prior studies have argued that a critical mass of three women directors is required to enhance the work of boards (this critical mass equals approximately $35 \%$ of the average board). As Shrader et al. (1997), who echo Rosener (1995), state: “One female board-member is often dismissed as a token. Two females are not enough to be taken seriously. But three give the board a critical mass and the benefit of the women's talents". ${ }^{7}$ Similarly, Kramer et al. (2007), who interview men and women directors, find that "the magic" occurs when three women directors are on a board, because this constitutes a critical mass sufficient to allow the others to notice the women directors' opinions, rather than their gender. ${ }^{8}$ In this study I shall examine whether having a critical mass of three directors of the same gender indeed makes a difference.

\section{Data and Methodology}

\subsection{Backgrounds on GBCs and Their Directors}

Thirty-four GBCs operate in Israel in various fields, including infrastructure, military technology, construction/housing, and services. Table 1 provides a list of the universe of the GBCs. All GBCs are overseen by the Government Companies Authority, which represents the government in its role as a shareholder. The size of these companies varies greatly: some companies employ only tens of employees, whereas others employ more than ten thousand. The annual income of the smaller GBCs is just a few million USD, whereas the parallel figure for the larger firms is one to four billion USD. The latter firms are very large in Israeli standards.

The bylaws of each GBC generally require that the board be made up of eight to twelve directors, with seven to ten serving directors being most common. The bylaws of each of the companies also specify which governmental minister appoints the directors of the company; in most cases it is the Minister of Finance and one other relevant minister. The only compensation given to GBC directors is a fixed compensation for each board or boardcommittee meeting they attend, which ranges between $\$ 200$ and $\$ 350$ per meeting, with the

\footnotetext{
${ }^{7}$ Shrader et al. (1997) and Rosener (1995) make the argument that having at least three women directors makes a difference, but they do not examine this claim empirically.

${ }^{8}$ Torchia at al. (2011) find evidence in support of the critical mass theory in their 2005-2006 study of Norwegian boards. $19 \%$ of those boards had three or more women directors. They find that boards with a critical mass of three women directors are significantly more innovative. Similarly, Joecks, Pull, and Vetter (2012) examine 151 German companies between the years 2000-2005. They find that women directors have a negative impact on firm performance (measured by ROE) when they consisted less than $40 \%$ of the board, but once they consist more than $40 \%$ of the board this effect reverses.
} 
exact amount a function of the company's size. ${ }^{9}$ Appendix A provides additional information on GBCs and their directors.

Since 1993 the Israeli Government Companies Law has required that the boards of GBCs in which the government holds at least $50 \%$ of the shares be composed in a way that "gives appropriate representation to women". ${ }^{10}$ This law is enforced by a designated committee that oversees the directorship appointment process. In practice, women directors constituted 34\% of the GBC boards during the years 1997-2009. Of the eleven GBCs for which minutes are examined, nine meet the Law's 50\% condition and are therefore required to have "appropriate representation" for women. The other two do not meet the law's 50\% condition, and therefore are not required to have a minimal percentage of women directors.

Table 2 examines the representativeness of the GBC directors examined, specifically, the differences between the background of the GBC men directors versus that of the GBC women directors, in comparison to other benchmark-boards (public Israeli, public Norwegian, public Swiss, and American S\&P 500 companies; sources are specified in Table 2). Table 2 demonstrates that the background of the GBC directors, and the also the difference between the backgrounds of the men versus the women GBC directors, is similar to that documented for boards in other countries. ${ }^{11}$ As is evident from that table, the male directors serving on the boards of the eleven GBCs examined were older than their women fellow-directors - a phenomenon which has also been documented for the other four benchmark-boards for which data is available; possessed more executive experience ${ }^{12}-$ this too is documented for all other benchmark-boards mentioned above; but were less educated than the women - which is also documented for Israeli and Norwegian companies, although not for the Swiss ones.

In sum, the GBC directors examined have backgrounds similar to those of directors in other counties, and the differences between the backgrounds of male and female directors

\footnotetext{
${ }^{9}$ The compensation the GBC directors received was quite similar to that outside directors of Israeli public companies were permitted to receive until 2008: a fixed annual income no larger than $\$ 3,500$, and an additional $\$ 180$ per meeting. Starting from 2008, a change in the "Rules Applying to Directors of Public Companies" allowed outside directors of Israeli public companies to receive substantially higher compensation: they were permitted to receive a fixed annual compensation ranging between $\$ 5,000-\$ 35,000$ and an additional \$280$\$ 1300$ per meeting, the exact amount depending on the size of the firm and the directors' experience. See Lavi, 2007.

${ }^{10}$ Here, as elsewhere in this paper, all translations from Hebrew are by the author.

${ }^{11}$ This conclusion is also consistent with Adams and Funk (2012), who examine Swedish boards and show that gender gaps between men and women directors in Sweden are similar to those in the United States.

${ }_{12}$ Most studies define executive experience as having served as a CEO or in an executive position in an organization, such as head of a functional unit, partner/ principal, or vice president. However definitions vary some from one study to the next.
} 
of GBCs is consistent with that documented for boards in other countries. In addition, the legal requirements and responsibilities of GBC boards are virtually identical to those of other boards in other countries, including the United States. For all these reason, the impact of gender on the dynamics of Israeli GBC boards may well reflect its impact in other boards around the world.

\subsection{Data and Methods}

I have been allowed access to unique data: detailed minutes of board- and board-committee meetings for a period of one year for eleven GBCs. ${ }^{13}$ The calendar year studied was 2007 (2 companies), 2008 (8 companies), or 2009 (one company). Nine of the eleven companies examined provided minutes of both board meetings and meetings of board-committees; the other two supplied only the former. These minutes aggregate to 4,758 pages, which document 402 meetings of the boards or their committees (155 and 247, respectively), in which according to my tabulation - 2459 decisions were made or updates were given (1422 and 1037, respectively). Confidentiality agreements preclude identification of the specific firms in the sample. However, all eleven firms are among those listed in Table 1. They are of different size, as measured by annual income, with a tendency toward the larger GBCs, and tend to reflect the different fields in which the GBCs operate.

To allow a structured analysis of the data, I coded the minutes according to the principles of content-analysis methodology (Krippendorff, 2004; Lieblich et al., 1998). Content-analysis methodology is a "systematic replicable technique for comprising many words of text into fewer content categories, based on explicit rules of coding" (Stemler, 2001). All coding was done manually because the coding guidelines defined require a comprehensive understanding of the content of the meetings. The essentials of the coding guidelines are as follows (for a more detailed description see Appendix B):

a. General information. For each issue discussed the type of meeting (board/boardcommittee) at which it was discussed was recorded, and whether the issue was merely presented as an update or, alternatively, culminated in a decision made by the board.

b. Aggregate topic-subjects. Each topic discussed or decision made was coded under one of the following five aggregate topic-subjects: audit, business issues, financial issues, formal issues, and personnel and benefits. These aggregate topic-subjects were further broken down into 23 topic-subjects, as defined in Appendix B.

\footnotetext{
${ }^{13}$ I was given access to these minutes because I worked at the GCA.
} 
c. Further updates. A Case in which the board requested to receive further information or an update on the subject discussed. Appendix $\mathrm{C}$ provides illustrative examples. When only one director requested the update, this director's name was recorded.

d. Taking an initiative. A case in which the board took an action/an initiative. For example: The board approved a lease it was asked to approve, yet decided to introduce a few revisions of details; it took an active part in defining the steps/actions that should be taken; or it delved into an issue presented to it, discussed the issue, and finally, formulated and adopted a new alternative policy. Appendix $\mathrm{C}$ provides illustrative examples. When only one director took the initiative, this director's name was recorded.

e. Board composition. For each meeting, the total number of attending directors was coded, as was the number of attending women directors and outside directors. ${ }^{14}$

f. Supervision. All topic-subjects (defined in Appendix B) were divided according to whether they were of supervisory or managerial nature. Supervisory issues include the issues for which boards are expected to oversee top management, but not to make the managerial decisions themselves. Managerial issues include the type of issues for which boards are expected (by law, for example) to be active. Supervisory topic-subjects are defined as: appointment of members, approving minutes of earlier meetings, audit issues, choosing a chairman for the meeting, contracting/ purchases, financial reports, formal issues, legal issues, personnel and benefits, ratification of audit committee, ratification of human resources committee, ratification of operational committee, ratification of financial committee, and regulation and government. Managerial topic-subjects are defined as: appointing/ firing an executive, budget, business issues, business projects, cross-firm issues, investment/ finance, ongoing general issues, organizational change, and strategic issues.

g. Consistency. All coding was done by the author. ${ }^{15}$ To assure consistent standards, she reviewed all coding several times.

\section{Are Gender-balanced Boards More Active?}

In this Section I follow the argument made by Shrader et al. (1997), Rosener (1995), and Kramer et al. (2007), that a critical mass of three women directors will catalyze board activeness/performance. I examine whether this is indeed the case "below the surface", i.e., in

\footnotetext{
${ }^{14}$ Outside directors are defined as directors who are not employed by the government or by the firm.

${ }^{15}$ The minutes were made available only to the author and a few scholars that signed a confidentiality agreement.
} 
the boards' meetings. In addition, to understand whether critical masses make a difference only regarding women, I examine the parallel argument - that a critical mass of three men directors catalyzes board activeness/ performance.

\subsection{Basic Econometric Model}

In each of the meetings a different board composition is in attendance. This variation in the gender composition of the directors in attendance allows an examination of how actions a particular board may choose to take or not to take, concerning a particular type of issue, are impacted by the gender composition in attendance, or by the presence of a critical mass of one or both genders.

To capture the extent a board is active, for each issue discussed I examine whether the board took the following actions: (a) requested to receive further information or an update, or (b) took an initiative, e.g., proposed the CEO take a specific action. Appendix C further demonstrates each of these two actions. These two actions are the most basic actions a board may choose to take or not to take when an issue is brought up at a board meeting or a board-committee meeting. By taking these actions board monitor (documented by the frequency updates are requested), and provide advice (documented by the frequency initiatives are taken).

The regressions allow examining how variations in the gender composition in attendance, for the same company, generate different levels of board activeness. The regressions are conducted on the level of each issue discussed ("case"), denoted by $i$; at a particular meeting, denoted by $m$; of a particular company, denoted by $c$. The following equation is estimated:

$$
A_{c m i}=G_{c m}^{\prime} \lambda_{1}+\alpha_{c}+\beta_{t}+X_{c m}^{\prime} \lambda_{2}+I_{c m i}^{\prime} \lambda_{3}+\varepsilon_{c m i}
$$

$A_{c m i}$ is a binary variable that equals one if the board took an action and zero otherwise. An action is defined as a case in which the board (a) requested to receive further information or an update, or in alternative specifications (b) took an initiative, e.g., suggested which action be taken by the company. $G^{\prime}{ }_{\mathrm{cm}}$ is a vector that captures the primary independent variables the gender composition in attendance, which varies from meeting to meeting. Specifically, $G^{\prime}{ }_{c m}$ includes the fraction of women directors in attendance, the square of the fraction of women directors in attendance, a dummy variable documenting whether a critical mass of at least three women directors was in attendance, and a dummy variable documenting whether a critical mass of at least three men directors was in attendance. 
$\alpha_{c}$ controls for company fixed-effects. $\beta_{t}$ controls for the year for which the minutes were examined (2007, 2008, or 2009). $X^{\prime}{ }_{c m}$ is a vector that captures the characteristics of the directors (excluding gender), and for the existence of a CEO: the fraction of attending outsiders, the total number of attending directors, the fraction of attending directors with an MA/ MBA, ${ }^{16}$ the average number of years of executive experience of the attending directors, and a dummy that equals one if the company was in the process of replacing its CEO at the time the issue was discussed. $I^{\prime}{ }_{c m i}$ controls for the type of issues that was discussed via 22 dummy variables controlling for the 23 topic-subject categories defined, as listed in Section 3.3.f and detailed in Appendix B. $I^{\prime}{ }_{c m i}$ also includes a dummy that equals one if the issue discussed was one of supervisory nature rather than managerial as defined in Section 3.3.f. For those analyses including observations from both board and board-committees, $I_{c m i}^{\prime}$ includes a dummy that equals one if the observation occurred in a board meeting (as opposed to a board-committee meeting). ${ }^{17}$ Following Angrist and Pischke (2009), who describe the problems that arise if of a small number of clusters is used to estimate the errors, I do not cluster errors on firm level (since only 11 firms are examined). Rather I cluster errors on the meeting level. ${ }^{18}$

\subsection{Findings}

Table 3 presents summary statistics on the minutes-data database constructed. As documented in this table, women directors comprised on average $37 \%$ of the directors in attendance, and there exists a variation in the gender-composition in attendance. In board meetings, the average percentage of cases the GBC boards examined requested an update equaled $6.4 \%$, and they took an initiative in $6.8 \%$ of the cases; in board-committee meetings these figures were $17.1 \%$ and $12.1 \%$, respectively. These two actions provide a measurement of the extent boards were actively supervising and providing advice. To demonstrate the type of actions taken by the boards, as an example, I specify in Appendix $\mathrm{C}$ all actions taken by the boards examined with respect to one of the 23 topic-subject defined: the "budget" topicsubject.

\footnotetext{
${ }^{16}$ Data on experience and education was obtained from the c.v. and detailed form each potential director must submit to the committee that oversees the nominations of directors of GBCs. Based on these data, the average executive experience and higher education (MA/MBA) of all attending directors were calculated.

${ }^{17}$ See Section 3.3.f for a definition of supervisory issues and the List of Topic-subjects in Appendix B.

${ }^{18}$ Results that are clustered on meeting level are similar to the unreported results clustered on firm level.
} 
Table 3 also documents that on average, 8.1 directors attended board meetings, and 4.3 attended board-committees. Hence, in most cases less than six directors (are invited and) attend board-committee meetings, which means that these meetings cannot be attended, usually, by at least three directors of each gender. For this reason, this section only examines observations from board meetings.

An initial indication of how gender-composition impacts upon board activeness is offered by Figures 1a-1f, which are based on the 1313 issues discussed by the GBC boards at 155 board meetings. Figures $1 \mathrm{a}$ and $1 \mathrm{~b}$ report the average percentage of cases in which the boards examined requested to receive further information or an update, and those in which it took an initiative, broken down by the number of women directors in attendance (Figure 1a) and the number of men directors in attendance (Figure 1b). These figures document that both genders were more active when three or more directors of their own gender were in attendance. Table 4 provides a further breakdown, on the topic-subject level, of the issues for which boards chose to request an update or take an initiative. This table documents that boards were usually more active when a dual critical mass (three directors of each gender) was in attendance.

Figures 1c and 1d break down the frequency actions were taken by the boards according to whether or not a critical mass of each gender was in attendance. These figures demonstrate that boards were more likely both to request an update and to take an initiative when at least three women directors were in attendance (Figure 1c), and also when at least three men directors were in attendance (Figure 1d). Figure 1e reports the frequency boards requested an update, and Figure 1f reports the frequency boards took an initiative, both these figures are broken down by the percentage of women directors in attendance. Figures 1e-1f indicate that relatively gender-balanced boards tend to be more active: the likelihood that the board will take an action peaked when women comprised approximately $30 \%-40 \%$ of the board in attendance. Since on average 8.1 directors attended the board meetings, this indicates that when approximately three women directors were in attendance board activeness peaked.

Table 5 examines via OLS regressions whether this activeness pattern prevails after controlling for other relevant variables, as specified in the previous section. ${ }^{19}$ The main

\footnotetext{
${ }^{19}$ There has been a continuing debate about whether analysis in which the dependent variable is binary should be conducted via OLS regressions or, rather, via logistic regressions. In this study, in which the dependent variables examined are binary, I follow Angrist (2001) and Angrist and Pischke (2009) and report results of
} 
conclusion that emerges from the regressions presented in Table 5 is that the presence of a critical mass of three directors of each gender impacts positively, and at a significant economic magnitude, upon the likelihood that a board will take action. The results pertaining to a critical mass of women directors are particularly robust.

Regressions 1-2 in Table 5 examine the impact of the proportion of one gender (women) in attendance upon the likelihood that boards will request an update (Regression 1) or take an initiative (Regression 2). No significant linear or U-shaped relation is documented between the gender composition of boards and the variables measuring board activeness: the results for both independent variables documenting the presence of women directors fraction of women directors and its square - are statistically insignificant. Regressions 1 and 2 include only observations from board meetings. These non-significant results are also obtained (in unreported specifications) when the sample is restricted to board-committee meetings, when including observations from both board and board-committee meetings (and including a dummy that controls for whether the meeting was a board or a committee meeting), and also when including only the fraction of women directors in attendance in the equation and excluding the square of the fraction of women.

Nevertheless, these findings do not indicate that gender does not play a role in board activeness. Perhaps a certain region of gender composition catalyzes board activeness, as suggested by Figures 1a-1d. I explore this possibility by examining the impact of a critical mass or of a dual critical mass, i.e., at least three men and/or three women directors are in attendance. Regressions 3 and 4 in Table 5 include a dummy variable which equals one if a critical mass of three women directors was in attendance, and another dummy variable which equals one if at least three men directors were in attendance. These regressions demonstrate that a critical mass of women directors impacts positively and significantly upon the likelihood that boards will request further information or an update, and also upon the likelihood that they will take an initiative. A critical mass of men directors was found to impact positively upon both these outcomes, yet its impact is statistically significant only with regard to the likelihood that boards will request an update, and not with regard to the likelihood that boards will take an initiative. However, the insignificance of the latter result should be treated with certain caution, for it is possible that the relatively limited number of

OLS regressions. Nevertheless I have also conducted, but not reported, parallel logistic regressions. The results are very similar. 
observations in which a critical mass of men directors was not in attendance (as documented in Table 3) impinges, to a certain extent, upon the statistical significance of those finding.

The coefficients in Regressions 3-4 document that the economic magnitude of the impact of a critical mass of women directors is larger than the comparable one for men directors. For example, the presence of a critical mass of women directors almost doubles the likelihood that directors request an update. Specifically, as Table 3 reports, the average percentage of cases in which boards requested an update in board meetings was $6.4 \%$. As Regression 3 of Table 5 documents, the presence of a critical mass of women directors increases the likelihood that boards will request an update by $6.3 \%$. Put differently, compared to the average frequency an update was requested, a critical mass of women directors approximately doubled the likelihood that an update be requested. ${ }^{20}$ Regression 3 of Table 5 documents that the presence of a critical mass of men directors increases this likelihood by $3 \%$.

To address the possibility that one of the companies is driving these results, in unreported specifications I repeated eleven times the analysis presented in Regressions 3-4 of Table 5, in each analysis excluding a different firm. The results that are significant in Table 5 remain significant at the 1\%-10\% level. Taken together, Regressions 3-4 thus indicate that having a dual-critical mass significantly increases the activeness of boards, and that the impact of a critical mass of at least three women directors is particularly robust and large.

In Regressions 5 and 6 of Table 5 the dependent variable equals one if the boards either requested an update or took an initiative. Regression 5 documents that a critical mass of women directors significantly (at the 1\% level) increases board activeness, and that a critical mass of men directors has the same effect, but the significance (at the 10\% level) and economic magnitude of the latter are smaller. Regression 6 includes a dummy which equals one only if a dual-critical mass was in attendance - i.e., at least three directors of both genders. The coefficients for this dummy variable indicate that boards with a dual-critical mass were $10.2 \%$ more likely, than boards without such critical masses, to request an update or to take an initiative, the results being significant at the $1 \%$ level. Given that the average percentage of cases boards requested an update or took an initiative in board meetings equals $12.4 \%$ (Table 3), these coefficients document that compared to this average frequency,

\footnotetext{
${ }^{20}$ Comparing the frequency with which boards requested an update to the average percentage of cases in which boards requested an update is a conservative estimation. If we were to compare the frequency with which boards request an update when a critical mass of one or both gender is present to the frequency when a critical mass is not in attendance, the estimation of the economic magnitude would be even larger.
} 
boards were almost twice as likely to take one of these actions if critical masses of three directors of both genders were in attendance. In a parallel set of logistic regressions (not reported) the impact of a dual-critical mass is also found to be statistically significant, and its economic magnitude is very similar.

As an examination of robustness (not reported) I analyze whether, perhaps, only two directors of a certain gender might suffice to compose a critical mass that impacts significantly upon the actions boards take. I do not find evidence that critical masses of two directors are sufficient to catalyze board activeness, whether in board meetings or in boardcommittee meetings. These findings confirm, once again, that a critical mass of three directors of each gender is required to generate a significant impact. ${ }^{21}$

In additional specifications (not reported) I examined how gender impacts upon disagreement (the board not voting in line with the CEO's proposal) and upon dissension (the board not voting unanimously). This analysis includes only the 1422 cases (of the 2459 cases) in which the boards examined not only discussed an issue at a board or a boardcommittee meeting but also concluded its discussion with a vote. This analysis examines whether the percentage/ number of women directors, or the presence of a critical mass of one or both of the genders, impacts significantly upon the likelihood that boards will vote against their CEO's proposal, or upon the likelihood that the board will vote non-unanimously. No such significant relation is found, neither for disagreement nor for dissension. This suggests that the proportion of each gender in attendance, and the presence of a critical mass of each gender, impact upon board activeness, rather than upon the likelihood that disagreement or dissension will emerge.

In sum, boards were found to be most active when a dual-critical mass was in attendance - at least three men and three women directors. These results are particularly driven by the presence of a critical mass of women directors.

\subsection{Instrument Variables Analysis}

It is possible that men and women directors have different attendance patterns. Specifically, it is possible that directors of one gender will more frequently attend meetings that are expected

\footnotetext{
${ }^{21}$ In addition, in unreported regressions, I examine whether the presence of a minority board member - in the case of the Israeli companies examined, an Arab, impacts upon the likelihood that boards will take action (i.e., request an update or take an initiative). Eight of the companies examined had one minority director, at least for part of the year examined. I do not find that one minority director impacts significantly upon actions boards take. Perhaps this highlights once again that one director of a particular ethnic/social/gender subgroup is not sufficient to impact upon board activeness.
} 
to require high involvement and activeness from the board, while directors of the other gender will prefer to attend meetings that are expected to require low levels of activeness. A director can quite easily establish such expectations based on the agenda and other materials he or she receives (usually at least several days) prior to each meeting. If this is indeed true, the model applied in the previous section should control for the likelihood that a director of a particular gender will choose to attend a particular meeting in which a particular issue is expected to be discussed. ${ }^{22}$

In this section I address the concern that non-random attendance may be driving the results, and that attendance may be driven by other factors included in the error term, such as whether directors expect high versus low involvement to be required. I introduce here a model similar to the one presented in Section 4.1, with one difference: the model in this section assumes that the presence of critical masses of three women directors and three men directors is endogenous. Accordingly, the model includes exogenous instrument variables that control for the likelihood that a critical mass of women directors, and a critical mass of men directors, will choose to attend a particular board meeting in which a particular issue is discussed. Exogenous variables exist as a result of the customary ways in which meetings are scheduled.

Frequently, committee meetings are scheduled on the same day as board meetings, just before or immediately after the board meeting. Because different directors sit on different board-committees, there exists a variation in the total number of meetings men and women directors have on a day a board meeting takes place. If a director is a member of a boardcommittee that meets before or after the board meeting, he or she has a stronger incentive to attend (both of) these meetings. This is because the only compensation GBC directors receive is a fixed amount for each meeting they attend (as described in Section 3.1). Hence, a director who has a board meeting and a board-committee meeting scheduled on the same day must commute only once (since the meetings are held at the same location) but will receive compensation that corresponds to the number of meetings he or she attends. In addition, regardless of the financial compensation, directors usually want to be involved, and therefore they may prefer attending meetings on days in which they have an increased opportunity to do so - the days they have more than one meeting scheduled.

\footnotetext{
${ }^{22}$ The attendance rates of GBC men and women directors examined were similar: on the level of the individual directors, the average percentage of meetings a director was invited to but did not attend, equaled $20 \%$ for women directors and $19 \%$ for men directors. Nevertheless, non-random attendance may exist.
} 
The 2SLS model introduced in this section uses this information on the day boardcommittee meetings are scheduled to instrument for attendance. The model instruments for the presence of a critical mass of women directors using the number of women directors that were invited to at least one board-committee meeting on the day a particular issue was discussed at a particular board meeting. A parallel variable is constructed to instrument for the presence of a critical mass of men directors. Using data concerning the number of scheduled board-committee meetings for each gender as IVs controlling for the likelihood that women and men directors attend board meetings conforms to the requirements from an IV: As will be shown, these IVs impact significantly (at the $1 \%$ level) upon attendance, of both men and women directors. In addition, because the meetings are in the vast majority of cases scheduled months in advance, the IVs have no direct impact on the likelihood that boards will take an action (i.e., request to receive an update or to take an initiative).

Specifically, usually each firm has its own tradition concerning the number of meetings the board and board-committees hold during a given period (e.g., one audit boardcommittee every quarter). Depending on the firm, every quarter, half-year or year the firm's secretary notifies the directors of the schedule of upcoming meetings. Since numerous people must attend these meetings (directors, employees, auditors, external consultants, etc.) in the vast majority of cases the meetings are indeed held on the date and time initially scheduled. However, the agendas of the meetings are determined only after the meetings are scheduled, usually one to three weeks prior to each meeting. Therefore, whether or not a boardcommittee is scheduled on a particular day should not be correlated with the error term of the 2SLS equation, which includes the expectations of directors that the meeting be one which requires a high/low level of board activeness. Accordingly, using the notations introduced in Section 4.1, the following 2SLS model is defined:

$$
A_{c m i}=C M W_{c m i}+C M M_{c m i}+\alpha_{c}+\beta_{t}+X_{c m}^{\prime} \lambda_{2}+I_{c m i}^{\prime} \lambda_{3}+v_{c m i}
$$

The difference between the OLS model, specified in Equation (1), and the 2SLS model, specified in Equation (2), is that the primary variables in the latter equation documenting the gender composition of the board at the time an issue was discussed (denoted in (1) by $G^{\prime}{ }_{\mathrm{cm}}$ ) are assumed to be endogenous in Equation (2). These endogenous variables are denoted in (2) by $C M W_{c m i}$, which indicates that three women directors were in attendance, and $C M M_{c m i}$, which indicates that three men directors were in attendance. To solve this equation, as mentioned, two exogenous variables are introduced: $\mathrm{CoW}_{c m i}$ is an instrument which equals the number of women directors that were invited to at least one board-committee meeting on 
the same day issue $i$ was discussed at the board meeting, and $C_{c m i} M_{c m}$ is the parallel variable for men directors. Accordingly, a 2SLS model that consists of three equations is defined, which includes the following two first-stage equations:

$$
C M W_{c m i}=\operatorname{CoW}_{c m i}+\operatorname{CoM}_{c m i}+\alpha_{c}+\beta_{t}+X^{\prime}{ }_{c m} \lambda_{2}+I_{c m i}^{\prime} \lambda_{3}+\varepsilon a_{c m i}
$$

and

$$
C M M_{c m i}=C o W_{c m i}+\operatorname{CoM}_{c m i}+\alpha_{c}+\beta_{t}+X_{c m}^{\prime} \lambda_{2}+I_{c m i}^{\prime} \lambda_{3}+\varepsilon b_{c m i}
$$

In Appendix D I address potential concerns related to the exclusion restriction requirement. First, I examine the possible concern that boards discuss different types of issues at board meetings scheduled on days on which also a board-committee meeting is scheduled, versus board meetings scheduled on days on which no additional board-committee meeting is scheduled. Panels 1 and 2 of Appendix D show that there is no such statistically significant difference. I also address the concern that firms adjust the type of issues bought up for discussion depending on whether the board is expected/ is gender balanced: Panel 3 of Appendix D documents that the type of issues discussed do not change significantly given hat the board is or is not gender balanced.

The results for Equations (2)-(4) are reported in Table 6. Regressions 1-2 of Table 6 report the first-stage equations (Equations (3) and (4), respectively). As these first-stage regressions document, indeed the IVs significantly impact upon the potentially endogenous variables. Regression 1 shows that the number of women directors that were invited to two or more meetings on the day issue $i$ was discussed impacts significantly, at the $1 \%$ level, upon the likelihood that a critical mass of three women directors attends a board meeting. Similarly, Regression 2 documents parallel results for men directors, the results being significant at the 5\% level. I report the Angrist-Pischke multivariate F-test described in Angrist and Pischke (2009). This F-test is informative for a model with multiple endogenous regressors and multiple instruments, which is the case in this analysis. For both first stage regressions, the Angrist-Pischke F-test are larger than the classic F=10 threshold suggested by Stock et al. (2002) as the minimal threshold required to conclude that the instruments used in a 2 sls model are strong.

The results of the 2SLS analysis (Equation (2) above) are reported in Regressions 36 of Table 6 . The dependent variable in these regressions is a binary variable that equals one if the board requested to receive further information or an update (Regression 3), took an initiative such as suggesting which action should be taken (Regression 4), or either requested 
an update or took an initiative (Regressions 5-6). As Regressions 3-6 document, consistent with the results presented in Section 4.2, the results presented in this section indicate that having a dual critical mass, and particularly one that includes a critical mass of women directors, significantly increases the likelihood that the board will request an update or/ and take an initiative. Hence, the 2SLS analysis confirms the results from the previous section.

The economic magnitude of the impact of critical masses of men and women directors is substantially larger in the 2SLS analysis compared to that documented in the OLS analysis. However, by definition, the 2SLS model is less efficient than the OLS model, and this may cause inaccurate estimates (e.g., Larcker and Rusticus, 2010). To examine whether the 2SLS model is indeed required in this case to solve a problem of endogeneity, and accordingly, if its economic magnitude is more reliable, I report the Sargan statistic (only for Regression 5, which includes two instruments and one potentially endogenous variable), and then conduct a Durbin-Wu-Hausman test for each of the specifications reported in Regressions 3-6 in Table 6. The Sargan statistic reported implies that the test of overidentifying restrictions cannot reject the null hypothesis that the instruments used are uncorrelated with the residuals from the 2SLS estimation. These results indicate that the IVs used are jointly valid, and we may proceed to a Durbin-Wu-Hausman test.

As the figures reported for Regressions 3-6 of Table 6 indicate, for all these specifications the Durbin-Wu-Hausman test fails to reject, at the $1 \%$ level, the null hypothesis that no difference exists between the 2SLS and the OLS estimates. Hence, the results of the Durbin-Wu-Hausman test imply that no systematic difference exists between the OLS and the 2SLS results. Therefore, given that the 2SLS results are biased and inconsistent in finite samples, in this case the estimates of the OLS model are those that provide the most accurate information on the magnitude of the impact of critical masses of women and men directors. The contribution of the 2 sls analysis is that it demonstrates that the significant and positive impact of a critical mass of women directors is not driven by non-random attendance.

In sum, the results in this section reinforce the conclusion that appointing gender balanced boards catalyzes board activeness.

\section{How Critical Masses Relate to Financial Performance}

The findings in the previous section show that the presence of critical masses of women directors, and to some extent of men directors, impel boards to work harder. This leads to the question: Are these patterns also evident above the surface, i.e., is the financial performance of firms that have one or two critical masses of directors superior to that of firms that do not 
have one or two critical masses? To address this question I take advantage of the unique setting offered by GBCs - they have a relatively large number (and fraction) of women directors. I examine whether critical masses of men and women directors are positively related to financial performance. To allow a sufficient number of observations, I include in this analysis the universe of the 34 GBCs for the years 1997-2009 for which data is available. These data were obtained from an internal database of the Government Companies Authority and from the annual reports it published. As described above, this type of analysis may suffer from endogeneity and/or from reverse causality. However, if this analysis documents patterns consistent with those documented "below the surface" (examined in Sections 4.2-4.3), those parallel patterns would provide support for the conclusion that the positive impact of gender diversity on board activeness trickles up to financial performance, and also leads to enhanced financial performance. ${ }^{23}$

Figures 2 provide an initial visual indication of the relation between critical masses of women directors on the one hand, and financial performance on the other. I focus in this analysis on critical masses of women directors because I do not have sufficient variation in the data pertaining to men directors: in $53 \%$ of the observations there was a critical mass of three women directors appointed to the board, whereas in $94 \%$ of the cases there was one of men directors. The average percentage of women directors equaled 31\%, and the S.D. 0.15. Put differently, usually there was a shortage of women directors to create a gender-balanced board.

Figure 2 report the average return on equity (ROE) and the net profit divided by sales (net profit margin) broken down according to whether or not a board had a critical mass of at least three women directors. Observations (of ROE and of net profit margin) that are smaller or larger than four standard deviations are excluded from the analysis in this section. As Figure 2 shows, the ROE of companies that had boards with at least three women directors was almost twice as large compared to the ROE of companies that did not have a

\footnotetext{
${ }^{23}$ The tradeoff of this study is that it provides an in-depth observation of the working of boards at the expense of the number of companies examined. Since all observations pertain only to eleven companies, I am only able to compute the association between the frequency boards take actions and firm performance, as opposed to conducting a robust analysis via regressions. I compute these correlations - between the average percentage of cases in which the boards examined took an action (either requesting an update or taking an initiative) on the one hand, and the change in a financial ratio between the year following the year for which the minutes were examined and the year for which the minutes were examined, on the other (I adjust, i.e., inflate, the percentage of cases an action was taken for the two firms for which only minutes of board meetings were obtained). The Pearson correlations between the average percentage of cases boards took an action and: EBITDA/sales equals 0.51 (significance $=.106$ ); cash flow from operating activities/current liabilities equals 0.57 (significance $=$ .064 ); ROA equals 0.26 (significance $=.425$ ). Needless to say, correlations do not provide firm evidence that the actions examined directly improve firm performance.
} 
critical mass of women directors. Similarly, the net profit margins of the former firms are almost three times larger than those of the latter.

Table 7 examines the relation between gender composition of boards and financial performance via OLS regressions using the panel data described earlier in this section. The dependent variable in these regressions is ROE (Regressions 1-3), or alternatively, net profit margin (Regressions 4-6). The primary independent variables are the fraction of women directors appointed to the board and its square, a dummy that equals one if at least three women directors were appointed, and a dummy that equals one if at least three men directors were appointed. In addition, the regressions control for the fraction of outsiders appointed, the total number of directors appointed, and the tenure of the CEO. Year and firm dummies are included as specified in Table 7. Errors are clustered on firm level.

The results in Table 7 do not document a significant linear or U-shaped relation between the fraction of women directors and its square, and financial performance, measured both by ROE (Regression 1) and by net profit margin (Regression 4). When including in parallel unreported specifications only the fraction of women directors, and excluding its square, the results remain insignificant. These results are consistent with those of the previous section - that do not document a significant linear or U-shaped relation between gender and likelihood that an action be taken.

Similar to the findings in the previous section, Table 7 does document a significant positive relation between the existence of a critical mass of women directors and financial performance. Regressions 2 and 5, which do not include fixed year and firm effects, document that a critical mass of women directors increases the ROE and profit margin at the $1 \%$ and $5 \%$ level, respectively. Regressions 4 and 6, which include fixed firm and year effects, also document such significant results, at the $10 \%$ and $5 \%$ level, respectively. The average ROE of the GBC equaled 6.6\%, hence the results in Regression 3 document that a critical mass of women directors may be expected to increase the ROE by $18 \%$ (1.2\%/6.6\%). The average profit margin of the GBCs equaled 4.3\%, hence Regression 6 documents that a critical mass of women directors may be expected to increase the profit margin by as much as $90 \%$.

All specifications included in Table 7 document a positive relation between the existence of a critical mass of men directors and financial performance. However, this relation is significant only in Regression 2. Nevertheless, as mentioned, additional variation in the (non)existence of a critical mass of men directors is needed to conclude whether these variables are significantly related. 
In sum, consistent with the findings of the previous section, this section documents that companies with boards that have a critical mass of at least three women directors perform better than the companies that do not have such a critical mass. Taken together with the findings from Section 4.2-4.3 which document a causal positive relation between gender diversity and board activeness below the surface, the findings in this section suggest that this positive relation trickles-up to the financial performance of the firm.

\section{Gender Composition and the Activeness of Individual Directors}

The findings in Section 4 document that given that a critical mass of three women directors is in attendance, and to a certain extent a critical mass of three men directors, the board is expected to be approximately twice as active. This raises the question: Does this phenomenon occur because the men directors, the women directors, or both are more active when critical masses of each gender are in attendance? To answer this question I examine how having a critical mass of each gender impacts upon the likelihood that women directors will take an action, and how it impacts upon the likelihood that men directors do so.

For each case in which the board either requested to receive further information or an update, or made an impact, I record the gender of the director taking the action. If more than one director took the action, the action was not attributed to a specific director. I am able to link $69 \%$ of the actions that were taken to one specific director; the remaining actions were taken by more than one director, and therefore are not linked to a specific director and gender, and are not included in the analysis presented in this section. ${ }^{24}$

In the sample, men directors usually constituted a larger fraction of all attending directors. For this reason, all else equal, the likelihood that men directors take an action is larger than the likelihood that women directors do so. ${ }^{25}$ To adjust for the actual likelihood that men and women directors take action, I use the Horvitz-Thompson estimator of the mean (Horvitz and Thompson, 1952). This estimator allows adjusting the real probability of the general population, when unequal selection probabilities exist. This adjustment will allow

\footnotetext{
${ }^{24}$ Due to the limited size of the sample, it is not possible to conduct an analysis of the cases in which an action was taken by two or more directors by breaking down the gender of those taking the action into more refined categories (i.e., action taken only men directors, only by women directors, or by both genders).

${ }^{25}$ For example, if three women directors and six men directors attended a meeting, and two actions were taken by women and four by men, the probability that a woman and a man director take an action is equal. However, if one does not adjust for the relative fraction of women and men directors, and observes only the percentage of actions taken by each gender, because twice as many actions were taken by men the (misleading) conclusion would be that men directors are twice as active.
} 
comparing the economic magnitudes pertaining to women directors to those pertaining to men directors.

Accordingly, the adjusted likelihood that a woman director take an action, given the numbers of women directors in attendance is computed, and is denoted by $A W_{m i} * F W_{m i}^{-1} *$ 0.5 , and a parallel variable denoted by, $A M_{m i} * F M_{m i}^{-1} * 0.5$, is computed for men directors. $A W_{m i}$ is a binary variable that equals one if a woman director took an action (either requesting further information or taking an initiative), and $A M_{m i}$ is a parallel variable pertaining to men directors. $F W_{m i}^{-1}$ is the inverse of the fraction of women directors in attendance at a particular meeting in which a particular issue was discussed, and $F M_{m i}^{-1}$ is the parallel variable for men directors. 0.5 represents the proportion of each gender in a board in which both genders are equally represented, thereby providing each gender the same initial opportunity to take action. ${ }^{26}$

I examine how gender-composition impacts upon the likelihood that women directors take an action (Table 8, Regressions 1-3) and upon the likelihood that men directors do so (Table 8, Regressions 4-6). Accordingly, the dependent variable in Regressions 1-2 and 4-5, is the "adjusted likelihood that an action is taken". As a robustness examination, I also conduct a set of regressions in which the dependent variable is $A W_{m i}$, the raw binary variable that equals one if a woman director took an action (Regressions 3 of Table 8), or alternatively, $A M_{m i}$, that equals one if a man director took an action (Regression 6 of Table 8). The primary independent variables are the fraction of attending women directors and its square, a dummy which equals one if at least three women directors were in attendance, and a dummy which equals one if at least three men directors were in attendance. In addition, the regressions control for the independent variables specified in Section 4.1.

Regressions 1 and 4 in Table 8 document that each gender tends to be more active when more directors of its own gender are in attendance, but these results are not statistically significant. Regressions 2-3 in Table 8, which examine the impact of a critical mass of each gender on the probability that women directors take an action, document that having a critical mass of at least three women directors significantly (at the $1 \%$ level) increases the likelihood that women directors take an action. Similarly, Regressions 5-6, which examine the impact of

\footnotetext{
${ }^{26}$ Tuggle et al. (2012), who examines minutes of board meetings of public American companies, find that the fraction of directors of a given gender impacts positively upon the activeness of board members of that gender. Assuming this finding applies to the GBC boards as well, because the GBC boards included on average only $37 \%$ women directors, even after the Horvitz-Thompson adjustment, the adjusted likelihood that an action is taken may demonstrate the lower bound of board activeness of women directors, and the upper bound of board activeness of men directors, if the boards were precisely gender-balanced.
} 
critical masses of each gender on the likelihood that men directors take action, document that a critical mass of women directors increases significantly (at the 5\%-10\% level) the likelihood that men directors take action. Regressions 2-3 and 5-6 do not document that a critical mass of men directors impacts significantly upon the likelihood that either women or men directors will take an action.

The economic magnitude of the impact of a critical mass of women directors is quite large. The adjusted frequency that a woman director take an action in a board meetings averaged $2.9 \%$. Regression 2 of Table 8 indicates that compared to the latter average, this figure increases by $193 \%$ to $5.6 \%$ if a critical mass of women directors is in attendance. Similarly, Regression 5 shows that a critical mass of women in attendance increases by $95 \%$ the likelihood that a man director take an action. These results demonstrate once again that having a critical mass of women directors catalyzes the activeness of both men and women directors.

These finding are in line with previous studies that document that the presence of women seems to enhance individual team member's, and team, performance. For example, Charness and Rustichini (2011) examine how men and women play the Prisoners' Dilemma game depending on the gender of an audience observing their decisions. They find that both men and women players cooperate more (thereby probably maximizing their own total wealth and also that of the other participants) when they are observed by an audience of women, compared to an all-male or a mixed audience. Hoxby (2000) and Lavy and Shloser (2011) examine the impact of the gender composition of school classes on achievement tests, in the US and Israel respectively. Both studies find that both girls and boys perform better on achievement tests the higher the fraction of girl students in the class. With respect to boards, Adams and Ferreira (2009) find that men directors have fewer attendance problems the larger the proportion of women directors on the board. This suggests once again that the presence of women enhances performance, perhaps due to peer monitoring between genders.

In sum, the results in this section show that on the level of the individual director, a critical mass of women directors significantly increases the likelihood that individual women directors take action, and also that men directors take one.

\section{Does the Gender of Directors Matter When Boards are Particularly Needed?}

Firing and hiring the CEO, and bridging the gaps between CEOs are among a board's most important functions (Mace, 1971; and Weisbach, 1988). For this reason, and because CEO turnover is one of the few observable variables that may reflect the work of boards, CEO 
turnover has been addressed quite frequently in board studies (e.g., Weisbach, 1988; Adams and Ferreira, 2009). I choose to focus on this transitional period so as to gain a better understanding on how the gender of directors affects the working of boards during such periods when they are particularly needed. The following section (7.1) examines the impact of the gender composition of boards above the surface before a CEO is replaced. Namely, similarly to Adams and Ferreira (2009), the section examines how the gender of directors, combined with financial performance, impacts upon the likelihood that CEOs of GBCs be replaced. The next section (7.2) examines the impact of the gender composition of boards below the surface, i.e., at its meetings, during the periods a firm is between CEOs.

\subsection{Gender Composition and CEO Turnover}

This section examines whether given financial performance, the gender composition of boards impacts upon CEO turnover. This analysis is conducted using the panel data introduced in Section 5 - data on the universe of the 34 GBCs for the years 1997-2009. The data is examined via OLS regressions, reported in Table 9. The dependent variable in these regressions is a binary variable that equals one if the CEO ceased to serve in this position. The primary independent variables examined are the fraction of women directors appointed to each board, that latter dummy times ROE, a dummy that equals one if the board had a critical mass of three women on the board, that latter dummy times ROE, a dummy that equals one if the board had a critical mass of three men on the board, and that latter dummy times ROE. In addition, the regressions control for ROE, the fraction of outside directors, the total number of directors, the tenure of the CEO, and a dummy that equals one if the CEO was a woman. Year and firm dummies are included as specified in Table 9.

Regression 1 of Table 9 examines a linear relation between gender and performance on the one hand, and CEO turnover, on the other. As this regression shows, boards with a larger fraction of women directors were significantly more likely to experience a CEO turnover. However, they were significantly more likely to experience CEO turnover if financial performance was weak. These results are quite similar to those of Adams and Ferreira (2009) who examine American public firms. They find that firms with a higher fraction of women directors that also exhibit weak financial performance are especially likely to experience CEO turnover. Regression 2 in Table 9 examines a U-shaped relation between the gender composition interacted with financial performance, and CEO turnover. This regression documents that for the average ROE of GBCs, which equals $6.6 \%$, the fraction of women directors times the ROE decreases the likelihood that CEO turnover will occur if 
women comprise less than approximately $30 \%$ of the board, but increases it if they comprise more than approximately $30 \%$. This finding emphasizes once again that a board is more likely to cause a CEO turnover following weak firm performance if the board includes a minimal fraction of women directors.

Regressions 3-4 further highlight the latter point. These regressions include independent variables controlling for the presence of a critical mass of at least three directors of each gender, and each of the latter variables times ROE. Similarly to the results above, both Regression 3, which does not include fixed firm and year effects, and Regression 4, which does include these variables, document that boards with at least three women directors were more likely to experience CEO turnover. In contrast, boards with at least three men directors were less likely to experience CEO turnover. More importantly, these regressions document that boards with a critical mass of at least three women directors were more likely to experience CEO turnover when financial performance is poor. These results suggest once again that boards respond actively to poor financial performance by enhancing CEO turnover, when they are relatively gender-balanced - which in the case of boards means they include a critical mass of women directors. Regression 4, which controls for fixed year and firm effects, does not document that a critical mass of men directors impacts significantly upon CEO turnover. However, this result may be the consequence of the limited variation in the existence of critical masses of men directors, as discussed in Section 5.

In sum, Table 9 documents that companies with boards that include critical masses of women directors are significantly more likely to experience CEO turnover if performance is poor. Similarly, the results also document that once women directors constituted approximately $30 \%$ of the board and financial performance was weak, the company was more likely to experience CEO turnover.

\subsection{The Impact of the Gender of Directors when Boards are between CEOs}

This section explores whether the gender of directors impacts upon the working of boards during the periods that boards are perhaps most needed - during the period the CEO is replaced. Four of the firms examined replaced their CEO during the year that was examined, and all these firms had periods, in which they were literally "between" CEOs and had no serving CEO, for a period that lasted between several weeks and several months. Such periods occurred for one or more of the following reasons: the board requested the incumbent CEO to resign his position at very short notice, the selection process of the new CEO went on 
for at least three months, ${ }^{27}$ legal issues complicated and extended the selection process, or the newly selected CEO was not able to leave his former position from one day to the next.

Because the board is expected to step in immediately once it fires the CEO, or once it learns that the current $\mathrm{CEO}$ will not continue serving in this position, I define the "gap period" between CEOs as starting when the minutes document for the first time that the board is aware that the current CEO will not continue serving in this position, and as ending when the new CEO first attends a meeting of the board or of a board-committee. According to this broad definition, the gap periods experienced by the four companies that replaced their CEO lasted between three and seven months. This gap period is longer than the one mentioned in the previous paragraphs, since the gap period according to the latter definition usually starts before the incumbent CEO leaves the company.

An initial indication of the impact of the directors' gender "between CEOs" is offered by Table 8 (described in Section 6). This table shows that during the gap periods women directors were significantly more likely to be active, compared to periods in which the company had a CEO, whereas men directors tended to be less active during the gap periods (the results pertaining to men directors are not significant). These findings suggest that in times in which the firm is in particular need of the board's leadership, women directors are keener to step in.

Table 10 explores how a critical mass of women and men directors impact upon board activeness during these gap periods. This analysis is, once again, based on the minutes data described in Section 3, implementing the model presented in Section 4.1, while adding a few additional independent interaction variables, as will be noted. ${ }^{28}$ Regression 1 of Table 10 examines whether a linear or a U-shaped relation exists between the gender of directors and board activeness during the gap periods, compared to the non-gap periods. Accordingly, the primary independent variables examined are the fraction of women directors in attendance and its square, and interaction variables for each of these two variables with a binary variable that equals one if the firm was in a gap period at the time the issue was discussed. Regression 1, which examines whether a linear or a U-shaped relation exists between gender and the

\footnotetext{
${ }^{27}$ The GBC boards are required to publish an advertisement in the newspapers, inviting candidates to apply for the CEO position. In addition, usually several rounds of interviews are conducted, and in most cases the board sends at least the final candidates to an external private company that assesses the applicants. In practice, this process takes at least three months.

${ }^{28}$ Table reports results for one of the 22 topic-subject dummies used in this study and included in the model (but not reported in the other tables) - "appointing and firing an executive". This variable is reported in Table 10 to emphasize that the increased board activeness due to the gender composition is observed after controlling for the fact that in periods between CEOs, boards put a special emphasis on hiring a new CEO.
} 
likelihood that an action is taken during gap periods, does not document a significant relation between the fraction of one of the genders and board activeness, that depends on whether the company is during a gap period.

Regression 2 examines whether having a critical mass of women and/or men directors during gap periods matters. As in Section 4, because these regressions examine the impact of a dual critical mass which requires the attendance of at least six directors, Regression 2 includes only observations from board meetings. The independent variables are those specified in Section 4.1, which include variables controlling for the presence of critical masses of men and women directors. Two additional control variables are included in the equation - "CMW*between CEOs", which equals one if a critical mass of three women directors was in attendance and the firm was during a gap period, and a parallel variable for a critical mass of men directors - "CMM*between CEOs".

As the results in Regression 2 document, a critical mass of women directors is still found to impact positively, at the $10 \%$ level, upon the likelihood that the board take an action. Furthermore, the coefficient for "CMW*no CEO" indicates that particularly during gap periods, having a critical mass of women directors increases significantly (at the 5\% level) the likelihood that boards take an action. The average percentage of cases in which boards took an action at board meetings during gap periods equaled $24.8 \%$. Hence, having a critical mass of women directors in gap periods increased the likelihood that boards take an action by $75 \%([7.6 \%+11.1 \%] / 24.8 \%)$. In contrast, Regression 2 does not document that a critical mass of men directors impacts significantly upon board activeness during gap periods.

To include in the analysis a larger number of observations in which a critical mass of men directors was not in attendance, I include in Regression 3 of Table 11 all observations that occurred during gap periods, both from board meetings and from board-committee meetings, in which six or more directors were in attendance. Accordingly, these regressions include a dummy that equals one if the observation is from a board meeting. These regressions document once again that during gap periods a critical mass of three women directors significantly (at the 5\% level) increases the likelihood that boards take an action. Once again, Regression 3 in Table 10 does not document that a critical mass of men directors catalyzes board activeness.

In sum, women directors were found to be especially active in periods in which board activeness is essential - while the CEO is being replaced. In addition, having a critical mass of women directors during these periods was found to catalyze board activeness, consistent with the findings documented in Section 4. 


\section{Does the Gender of Directors Engender Differential Propensities?}

Adams and Funk (2012), who survey directors, find that men and women directors have significantly different values. ${ }^{29}$ Their findings demonstrate that although women directors may be more similar to men directors than the "average" woman, nevertheless, differences between men and women directors exist. Accordingly, Adams' and Funk's study may imply that because directors of different genders have different values, directors of each gender also have different relative advantages and/ or inclinations to specialize in certain types of tasks.

In the context of boards, appointments to board-committees are among the few observable variables that might reflect the relative skills or propensities of each gender of directors. Studies on board-committee appointments have documented that men directors are likely to be appointed to the executive committee ${ }^{30}$ (Kesner, 1998; Bilimoria and Piderit, 1994; and Peterson and Philpot, 2007), and to the compensation committee (Bilimoria and Piderit, 1994; Adams and Ferreira, 2009); Women directors are more likely to be appointed to the public affairs committee, (Bilimoria and Piderit, 1994 and Peterson and Philpot, 2007), to the audit committee (Adams and Ferreira, 2009), and to the corporate governance committee (Adams and Ferreira, 2009). Taken together, the studies on gender patterns of board-committee appointments suggest that women directors are more likely to be appointed to committees that conduct tasks oriented toward monitoring and sustaining the corporate governance of the company, while men directors are more likely to be appointed to the business-oriented/ managerial committees.

However, board-committee appointments are not occurrences determined by nature. Rather, usually the chairman of the board, or a few powerful directors decide, in practice, to which committee(s) each director is appointed. While some directors may be appointed to the committee(s) they prefer, others may not. This mechanism distorts the ability of scholars to determine, with confidence, whether women are appointed to certain committees because they are discriminated against and pushed to the less prestigious committees (as argued by

\footnotetext{
${ }^{29}$ Consistent with findings for the general population, compared to men directors, women directors were found to be less achievement and power-oriented, and more benevolent. However, in contrast to findings for the general population, compared to men directors, women directors who made it to the top were seeking more stimulation and risk, and were less tradition-oriented.

${ }^{30}$ The executive committee acts on behalf of the board during intervals between board meetings; the compensation committee reviews and approves the compensation of the CEO and of the executives; the public affairs committee oversees the media and community outreach policy; the audit committee oversees the quality of the companies' financial reports and its audit function; and the corporate governance committee assists the board in the fulfillment of its governance responsibilities.
} 
Bilimoria and Piderit, 1994) or, rather, there is no such discrimination, and women directors have a relative advantage for committees that require a specialization or a propensity to carry out monitoring or sustainability tasks (e.g., Kesner, 1988).

This section examines whether at the level of the individual board member, men and women directors have differential penchants or predispositions to take actions concerning different types of issues. If indeed, gender engenders a relative specialization, we may observe that as the board-committee appointment patterns document, women directors are more likely to take an action concerning supervisory issues, while men directors are more likely to take an action concerning managerial issues. I make the somewhat crude distinction between supervisory and managerial issues (to be detailed below) because boards are generally expected to fulfill two functions: to supervise the CEO, and to be involved in major managerial/strategic decisions (e.g., Adams and Ferreira, 2007; Schwartz-Ziv and Weisbach, 2012). Examining the tendency of each gender to be active with respect to each of these roles allows us to observe whether a particular gender has a "natural" inclination toward one or the other of these roles.

To examine whether such tendencies indeed exist, each issue discussed by the boards examined was categorized under one of twenty-three topic-subjects (see Appendix B for further information). Each of the twenty-three topic-subjects was classified as either supervisory or managerial. ${ }^{31}$ Managerial issues include the type of issues for which boards are expected (e.g., by law) to be active. Accordingly, managerial issues include, among others, the topic-subjects that pertain to business issues and to firing and hiring the CEO. In contrast, the supervisory issues include the type of issues that boards are expected to oversee, but not to carry out themselves. For example, approving a financial report is classified as supervisory because the board's role with regard to these reports is mainly verifying that they are properly conducted, rather than creating these reports themselves.

As in Section 6, for each of the cases in which the board took an action (either made an impact or requested to receive further information or an update) and it is possible to attribute that action to one director (69\% of all actions), I record the gender of the director who took the action. As in the previous section, if more than one director took the action I do

\footnotetext{
${ }^{31}$ Supervisory topic-subjects are defined as: appointment of members, approving minutes of earlier meeting, audit, choosing a chairman for the meeting, contracting/ purchases, financial reports, formal issues, legal, personnel and benefits, ratification of audit committee, ratification of human resources committee, ratification of operational committee, ratification of financial committee, and regulation and government. Managerial topicsubjects are defined as: appointing/ firing an executive, budget, business issue, business project, cross-firm issues, investment/ finance, ongoing general issues, organizational change, and strategic issues.
} 
not attribute the action taken to a specific director. The observations pertaining to board meetings are examined separately from those pertaining to board-committee-meetings since, as mentioned above, an internal nomination mechanism exists for board-committees, and that may lead to directors being appointed to committees that do not reflect their relative strengths or propensities.

Figure 3 presents the breakdown of the actions that were taken in board meetings by men directors, and those taken by women directors. The figure suggest that when a woman director takes an action, it is particularly likely to concern a supervisory issue: in $80 \%$ of the cases in which women directors took an action (i.e., requested an update or made an impact) in board meetings, the action pertained to a supervisory issue. The comparable figure for men directors was only $60 \%$. A two tailed t-test indicates that the difference between the likelihood that men versus women directors take an action pertaining to a supervisory issue is significant at the $1 \%$ level for observations pertaining to both board meetings and boardcommittees meetings, and at the 5\% level for observations pertaining only to board meetings, or only to board-committee meetings.

To compare the activeness of women versus men directors with respect to supervisory versus managerial issues I focus on the cases in which an action has been taken and compare the types of issues concerning which women directors were active to those concerning which men directors were active. This approach is equivalent to assuming that first men and women directors each choose their level of activeness. Only after this step, each director chooses the extent to which he or she wishes to specialize in supervisory tasks versus the managerial ones. Table 11 presents an analysis according to this rationale. This table assesses the likelihood that given that an action has been taken, if it pertains to a supervisory issue, it is likely to have been taken by a woman director. Because this approach assumes that the overall level of effort has already been determined - i.e., an action has been taken by the board, all OLS regressions reported in Table 11 include only cases in which the board took an initiative and/or requested an update (and for which it was possible to identify a single director who took the action).

The dependent variable in these regressions is a binary variable which equals one if the action the board took pertained to a supervisory issue as opposed to a managerial one. The primary independent variable is the gender of the director taking the action. In addition, the 
specifications include the control variables specified above in Section 4.1. ${ }^{32}$ Regression 1 examines the cases in which boards either requested an update or made an impact both in board meetings and in board-committee meetings. However, as mentioned, it is possible that women directors are appointed to the supervisory committees even when they prefer to be appointed to the managerial ones, which would increase the likelihood that women directors take an action in a board-committee that pertains to a supervisory issue. For this reason, I examine separately observations from board-committee meetings (Regressions 2), and those from board meetings, for which no additional nomination mechanism exists (Regression 3). This allows observing whether women directors have a tendency to be active with respect to supervisory issues when both men and women directors receive equal opportunities - in board meetings.

All three regressions reported in Table 11 provide evidence that relatively to men, women directors are significantly (at the $1 \%$ level) more likely than men to take actions with respect to supervisory issues as opposed to managerial ones, both in board meetings and in board-committees. The flip side of these findings is that, men directors were, significantly more likely than women directors to take actions concerning managerial issues.

Nevertheless, both genders do frequently take actions pertaining to both supervisory and managerial issues. As Figure 3 shows, women directors also take actions concerning managerial issues, and men directors frequently take actions concerning supervisory issues. In addition, in Regression 3, which examines only observations from board-committee meetings, the coefficient for the variable "action taken by woman" is more than twice as large than the comparable coefficient in Regression 2, which examines only observations from board meetings. The large coefficient documented in Regression 3, may indicate that women directors were somewhat excessively appointed to supervisory committees.

In sum, the findings provide support for the argument that women directors have, relative to men, a stronger inclination to focus on supervisory issues.

\section{The Impact of Gender on the Extent of Communication}

Economic models of boards stress that successful board performance depends on the existence of communication between the directors (e.g., Harris and Raviv, 2008; Malenko, 2011), and also between the board and the CEO (Adams and Ferreira, 2007). Similarly,

\footnotetext{
${ }^{32}$ The 22 topic-subject dummies are not included in the analysis because, by definition, they are correlated with the dependent variable.
} 
economic models analyzing the work of teams argue that communication in heterogeneous teams is costlier than in homogenous teams (Becker, 1957; Kandel and Lazear, 1992; Lazear, 1999; Hamilton et al., 2004).

Following these theoretical models, in this section I examine empirically whether the gender of directors impacts upon the extent of communication. I use the length of meetings as a proxy for the extent of communication. ${ }^{33}$ If communication between genders is costlier, then a more gender-balanced board is likely to demonstrate a decrease in the extent of communication. In addition, it is possible that one gender "specializes" in enhancing communication. This possibility would fall in line with the rationale presented in Lazear (1999) and Hamilton et al. (2004), who argue that different types of team members may have different useful skills that cumulatively enhance team performance.

To conduct an initial visual analysis of the impact of gender on the length of meetings, I standardize the length of the meetings. I start by documenting the raw length of each meeting, which is measured by the number of pages of minutes documenting each meeting. Since there are differences in the level of detail and the graphical presentation of the minutes from one firm to the other, I define a standardized length of meeting as the number of pages of minutes for a certain meeting divided by the average number of pages of minutes per meeting for that particular firm. Because board-committee meetings are usually shorter than board meetings, I standardize the minutes separately for board meetings and boardcommittee meetings (i.e., a board meeting of firm $c$ is compared only to board meetings of firm $c$, and a board-committee of firm $c$ is compared only to board-committees of firm $c$ ).

Hence, a standardized number of pages larger than one reflects a relatively long meeting, whereas a number smaller than one reflects a relatively short meeting. Figure 4 shows the standardized length of all 247 board-committee meetings broken down by the percentage of women directors in attendance. As this figure quite clearly indicates, the larger the percentage of women directors in attendance, the more likely that boards have longer discussions. As will be shown, the gender composition in attendance is not found to impact significantly upon the length of board meetings.

\footnotetext{
${ }^{33}$ I do not judge the quality of communication. Indeed, it is possible that longer discussions do not necessarily indicate communication is of better quality. However, in an analysis conducted (not reported), longer discussions were not found to be significantly associated with higher rates of dissension (i.e., that the board not vote unanimously) or with disagreement (i.e., that the board not vote in line with the CEO). This suggests that longer discussions are not associated with "clashing" communication.
} 
Table 12 further examines the impact of gender on the length of meetings via OLS regressions. Regressions 1-2 examine only board-committees, while Regressions 3-4 examine only board meetings. In these regressions, the number of pages of minutes serves as the dependent variable. The primary independent variable in these regressions is the fraction of women in attendance and its square. The control variables specified in Section 4.1 (which also apply on meeting level) are included in these regressions. In addition, Regressions 1-2 that pertain to board-committees include dummies that control for the specific type of boardcommittee examined. Regression 1 - which includes only the fraction of women directors, and Regression 2 - which includes also the square of the fraction of women directors, both document that a higher fraction of women directors significantly increases the number of pages of minutes. This suggests that when women directors constitute a higher fraction of the board-committee members in attendance, the extent of communication increases. The economic magnitude of this phenomenon is quite substantial: Hence, if for example, the percentage of women directors were to increase in a board-committee from $0 \%$ to $35 \%$, Regression 1 of Table 12 documents that the length of the meeting is expected to increase by $16.9 \%(4.984 * 0.35 / 10.3)^{34}$.

Regressions 3-4 examine only board meetings. These regressions do not document a significant linear or $U$ shaped relation between the gender of directors and the length of meetings. In additional specifications (not reported) the impact of a critical mass of three women directors and/or three men directors, on the length of board meetings was examined. Also in these specifications, no statistically significant impact was documented.

Perhaps, the differences between the findings pertaining to board-committees versus board meetings can be explained by the difference in the size of the "team": As Table 3 documents, on average, in board-committees only 4.3 directors attended, compared to 8.1 directors in board meetings. It may well be that when women are the minority gender in a large team, as opposed to a small one, the former situation may particularly impinge upon their ability to increase communication.

In sum, the findings of this section seem to imply that communication in board or teams is increased by the presence of women, although this study finds this effect is pronounced only in small teams.

\section{Summary}

\footnotetext{
${ }^{34}$ Table 3 documents that the average number of pages of minutes for board-committees is 10.3 .
} 
I find that boards with a dual-critical mass, defined as boards that have at least three directors of each gender in attendance, are more active than boards that do not have such a dual critical mass. These results are particularly driven by the existence of a critical mass of women directors. I find that boards with a dual-critical mass are approximately twice as likely to take an action in board meetings - both to request further information and to take an initiative. These findings are also documented for periods in which boards are particularly crucial when companies are between CEOs. These findings suggest that critical masses of each gender are required to allow boards to benefit from the potential benefits gender diversity may offer. Also above the surface similar patterns are documented: the ROE and the net profit margin of GBCs are found to be significantly larger in firms whose boards include a critical mass of at least three women directors - thereby becoming gender balanced boards. Taken together with the findings documenting a causal positive relation between gender balanced boards and the frequency they take actions, the findings pertaining to financial performance imply that the positive impact of a critical mass of women directors trickles up to the financial performance of the firm.

On the level of the individual directors, the study documents that both men and women directors are more active when a critical mass of three women directors is in attendance. In addition, women directors were found to be more likely than men directors to take actions on supervisory issues, and they were more likely to be active when companies were between CEOs. Last, having more women in board-committees was found to increase the extent of communication. These findings imply that each gender of directors has, to a certain extent, different skills and interests.

On the academic level, this study demonstrate that gaining access to the "black box", allows a more direct and delicate examination of the work of boards - in this case, of the impact of gender upon it. On the practical level, these findings suggest that, in a steady state, gender-balanced boards seem to have an advantage. 


\section{Bibliography}

Adams, Renee B. and Daniel Ferreira, 2009. Women in the Boardroom and Their Impact on Governance and Performance, Journal of Financial Economics, 94(2), 291-309.

Adams, Renee B. and Patricia Funk, 2012. Beyond the Glass Ceiling: Does Gender Matter?, Management Science 58, 219-235

Adams, Renee B., Benjamin Hermalin, Michael Weisbach, 2010. The Role of Boards of Directors in Corporate Governance: A Conceptual Framework and Survey, Journal of Economic Literature 48, 58-107.

Ahern, Kenneth R. and Amy K. Dittmar, 2012. The Changing of the Boards: The Value Effect of a Massive Exogenous Shock. Quarterly Journal of Economics 127(1), 137-197.

Allmendinger, Jutta, and J. Richard Hackman, 1995. The More, the Better? A Four-Nation Study of the Inclusion of Women in Symphony Orchestras, Social Forces 74(2), 423-460.

Angrist, Joshua D. and Jörn-Steffen Pischke, 2009. Mostly Harmless Econometrics: An Empiricist's Companion, Princeton : Princeton University Press.

Apesteguia, Jose, Ghazala Azmat, and Nagore Iriberri, 2012. The Impact of Gender Composition on Team Performance and Decision-Making: Evidence from the Field, Management Science $58,219-235$.

Bear, Julia A., and Anita Williams Woolley, 2011. The Role of Gender in Team Collaboration and Performance, Interdisciplinary Science Reviews 36 (2), 146-153.

Becker, Gary, 1957. The Economics of Discrimination, Chicago: University of Chicago Press.

Bilimoria, Diana and Sandy Kristin Piderit, 1994. Board Committee Membership: Effects of SexBased Bias, The Academy of Management Journal 37(6), 1453-1477.

Bloomberg, 2012. No Women on Facebook Board Shows White Male Influence, http://www.businessweek.com/news/2012-02-08/no-women-on-facebook-board-showswhite-male-influence.html.

Carter, David A., Simkins, Betty J. and Simpson, W. Gary, 2003. Corporate Governance, Board Diversity, and Firm Performance. The Financial Review 38, 33-53.

Catalyst, 2012. Women on Board, http://www.catalyst.org/publication/433/, accessed 28 June 2012.

Charness, Gary, and Aldo Rustichini, 2011. Gender differences in cooperation with group membership, Games and Economic Behavior 72, 77-85.

Craig A. Peterson and James Philpot, 2007. Women's Roles on U.S. Fortune 500 Boards: Director Expertise and Committee Memberships, Journal of Business Ethics 72, 177-196.

Dalton, Dan R., Catherine M. Daily, Jonathan L. Johnson and Alan E. Ellstrand, 1999. Number of Directors and Financial Performance: A Meta-Analysis, The Academy of Management Journal, 42(6), 674-686.

Erhardt, Niclas L., James D. Werbel and Charles B. Shrader, 2003. Boards of Director Diversity and Firm Performance, Corporate Governance: An International Review 11(2), 102-11.

Farrell, Kathleen A., and Philip L. Hersch, 2005. Additions to Corporate Boards: The Effect of Gender, Journal of Corporate Finance 11, 85-106. 
Government Companies Authority (Israel), Annual Reports on the Government Companies, 1997-2007.

Hamilton, Barton H., Jack A. Nickerson, Hideo Owan, 2004. Diversity and Productivity in Production Teams, Working Paper.

Harris, Milton and Artur Raviv, 2008. A Theory of Board Control and Size. The Review of Financial Studies 21(4), 1797-1832.

Hermalin, Benjamin E. and Michael S. Weisbach, 2003. Boards of Directors as an Endogenously Determined Institution: A Survey of Economic Literature, Economic Policy Review 9(1), 726.

Hoogendoorn, Hessel Oosterbeek, and Mirjam van Praag, 2011. The Impact of Gender Diversity on the Performance of Business Teams: Evidence from a Field Experiment, Tinbergen Institute Discussion Paper 074/3.

Hoxby, Caroline, 2000. Peer Effects in the Classroom: Learning from Gender and Race Variation, NBER Working Paper Series.

Israeli Stock Exchange Authority, 2010. Women on Boards (in Hebrew), http://www.isa.gov.il/Download/IsaFile_5625.pdf, accessed 28 June 2012.

Joecks, Jasmin, Kerstin Pull, and Karin Vetter, 2012. Women on Boards and Firm Performance: What Exactly Constitutes a 'Critical Mass'?. Working Paper

Kandel, Eugene and Edward P. Lazear, 1992. Peer Pressure and Partnership, The Journal of Political Economy 100(4), 801-817.

Kanter, Rosabeth Moss, 1977. Men and Women of the Corporation. Basic Books, New York.

Kesner, Idalene F., 1988. Directors' Characteristics and Committee Membership: An Investigation of Type, Occupation, Tenure, and Gender, The Academy of Management Journal 31(1), 66-84.

Kramer, Vicki W., Alison M. Konrad, and Sumru Erkut, 2006. Critical Mass on Corporate Boards: Why Three or More Women Enhance Governance, Wellesley Center for Women, Report No. WCW 11.

Krippendorff, Klaus 2004. Content Analysis: An Introduction to Its Methodology, Thousand Oaks, CA: Sage Publications.

Larker, David, and Tjomme Rusticus, 2010. On the Use of Instrumental Variables in Accounting Research, Journal of Accounting and Economics 49, 186-205.

Lavi, Victor, and Analía Schlosser, 2011. Mechanisms and Impacts of Gender Peer Effects at School, American Economic Journal: Applied Economics 3, 1-33.

Lazear, Edward, 1999. Globalization and the Market for Team-mates, The Economic Journal 109, C15-C40.

Lieblich, Amia, Rivka Tuval-Mashiach, and Tamar Zilber, 1998. Narrative Research: Reading, Analysis, and Interpretation, Thousand Oaks, CA: Sage Publications.

Malenko, Nadya, 2011. Communication and Decision-Making in Corporate Boards, Working Paper, Boston College.

Matza, David A., and Amalia R. Miller, 2011. A Female Style in Corporate Leadership? Evidence from Quotas. Working Paper. 
New York Times (by James Kanter), 2012.

http://www.nytimes.com/2012/03/05/business/global/eu-considers-quotas-for-women-inboardrooms.html?pagewanted=all.

Norman, Laurence, and Matina Stevis, Oct. 23, 2012. EU Shelves Women Board Quotas Plan, Wall Street Journal,

http://online.wsj.com/article/SB10001424052970203406404578074623918256116.html, accessed on Oct. 27.

Peterson, Craig A. and James Philpot, 2007. Women's Roles on U.S. Fortune 500 Boards: Director Expertise and Committee Memberships, Journal of Business Ethics 72, 177-196.

Rhode, Deborah L. and Amanda K. Packel, 2010. Diversity on Corporate Boards: How Much Difference Does Difference Make? Rock Center for Corporate Governance, Stanford University.

Rosener, Judy B., 1995. America's Competitive Secret: Utilizing Women as a Management Strategy. New York: Oxford University Press.

Ruigrok, Winfried, Simon Peck and Sabina Tacheva, 2007. Nationality and Gender Diversity on Swiss Corporate Boards, Corporate Governance 15(4), 546-557.

Schwartz-Ziv, Miriam and Michael S. Weisbach, 2012. What do Boards Really Do? Evidence from Minutes of Board Meetings, Journal of Financial Economics, forthcoming.

Shrader, Charles B., Virginia B. Blackburn, and Paul Iles, 1997. Women in Management and Firm Financial Performance: An Exploratory Study. Journal of Managerial Issues 9, 355372.

Spencer Stuart, 2011. Spencer Stuart Board Index, Chicago: Spencer Stuart

Stemler, Steve, 2001. An Overview of Content Analysis, Practical Assessment, Research and Evaluation, 7(17).

Stock, James H., Jonathan H. Wright, and Motohiro Yogo (2002). A Survey of Weak Instruments and Weak Identification in Generalized Method of Moments. Journal of Business and Economic Statistics 20, 518-529.

Tuggle, Christopher S., David G. Sirmon,, and Leonard Bierman, 2012. A Multi-Level Model of Minority Director Participation: Exploring Underlying Processes Linking Boardroom Diversity to Firm Performance. Working Paper.

Weisbach, Michael S., 1988. Outside Directors and CEO Turnover, Journal of Financial Economics 20(1), 431-460.

Williams Woolley, Anita, Christopher F. Chabris, Alex Pentland, Nada Hashmi, and Thomas W. Malone, 2010. Evidence for a Collective Intelligence Factor in the Performance of Human Groups, Science 330, 686-688.

Ynet (by Zvi Lavi), 2007. The Ministry of Justice is Increasing the Compensation of Outside Directors, http://www.ynet.co.il/articles/0,7340,L-3435614,00.html. In Hebrew, accessed 28 June 2012. 
Figure 1

\section{Actions Taken by Boards at Board Meetings}

Figures 1a-1f examine the 1313 issues discussed by the GBC boards at 155 board meetings. Figures $1 \mathrm{a}$ and $1 \mathrm{~b}$ report the average percentage of cases in which the boards examined requested to receive further information or an update, and those in which it took an initiative - e.g., suggested which action should be taken, broken down by the number of women directors in attendance (Figure 1a) and the number of men directors in attendance (Figure 1b). Figures 1c and 1d break down the frequency actions were taken by the boards according to whether or not a critical mass of at least three women directors was in attendance (Figure 1c), or one of at least three men directors (Figure 1d). The error bars in Figures 1c-1d indicate the 95\% confidence interval. Figures 1e and 1f present the average percentage of cases in which the eleven GBC boards requested to receive further information or an update (Figure 1e), or made an impact (Figure 1f), broken down by the percentage of women among the directors in attendance. The shaded areas in Figures 1e and 1f indicate $95 \%$ confidence interval.

Figure 1a - Number of Women Directors and Frequency Action is Taken

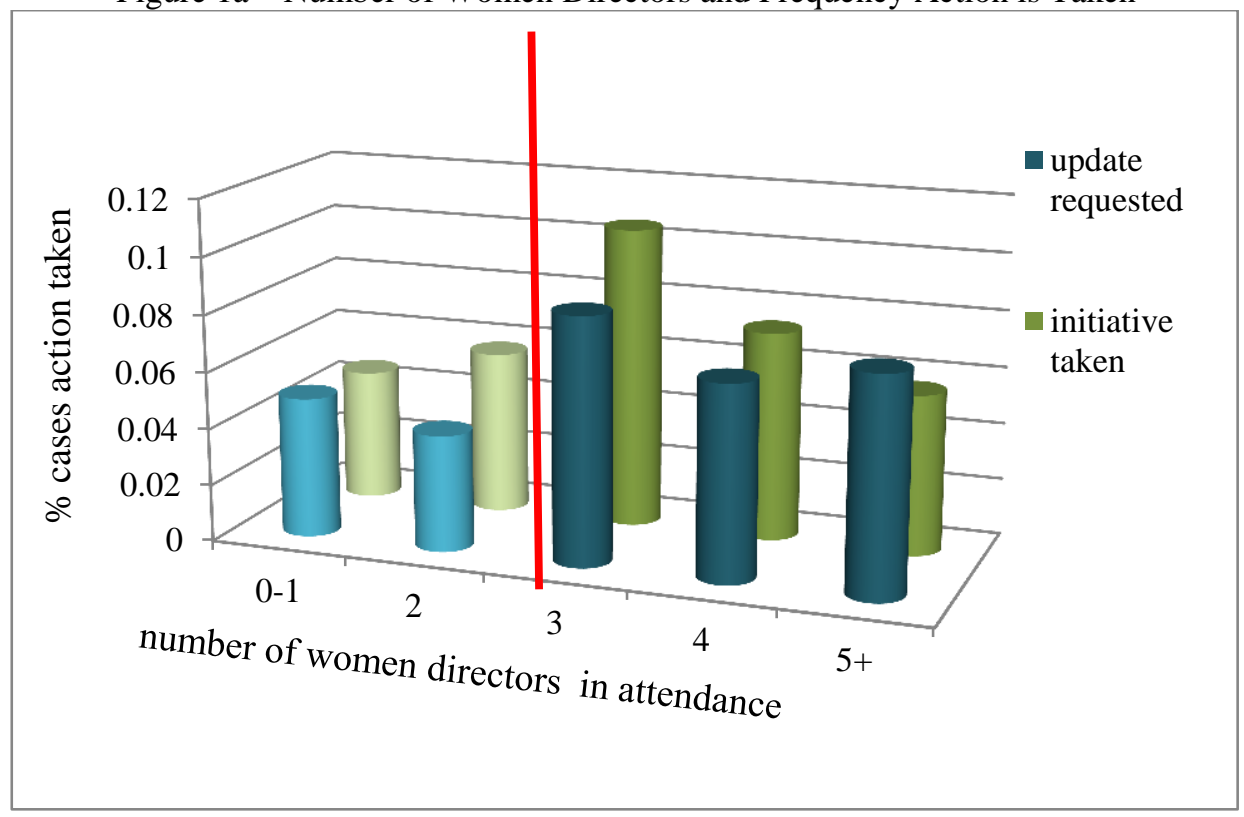

Figure $1 b-$ Number of Men Directors and Frequency Action is Taken

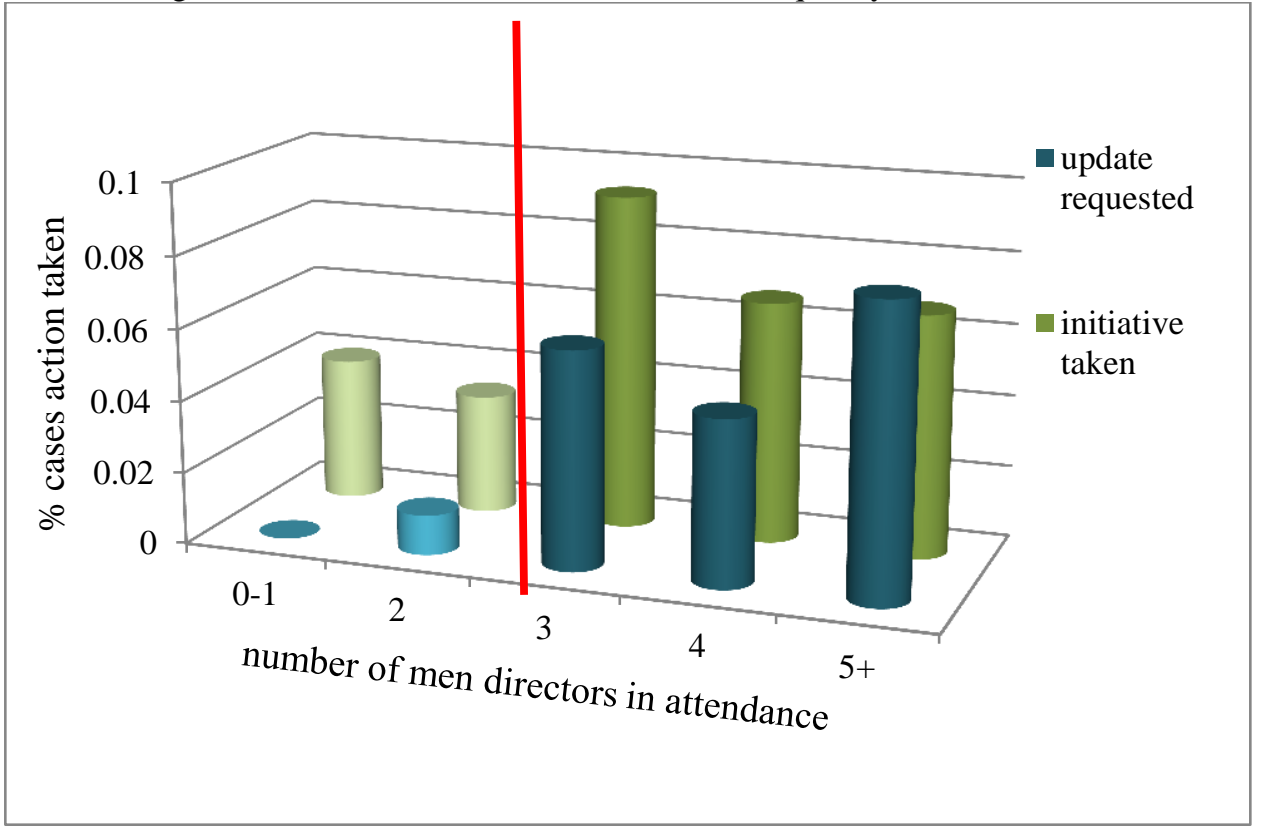


Figure 1c - Critical Masses of Women Directors and Frequency Action is taken

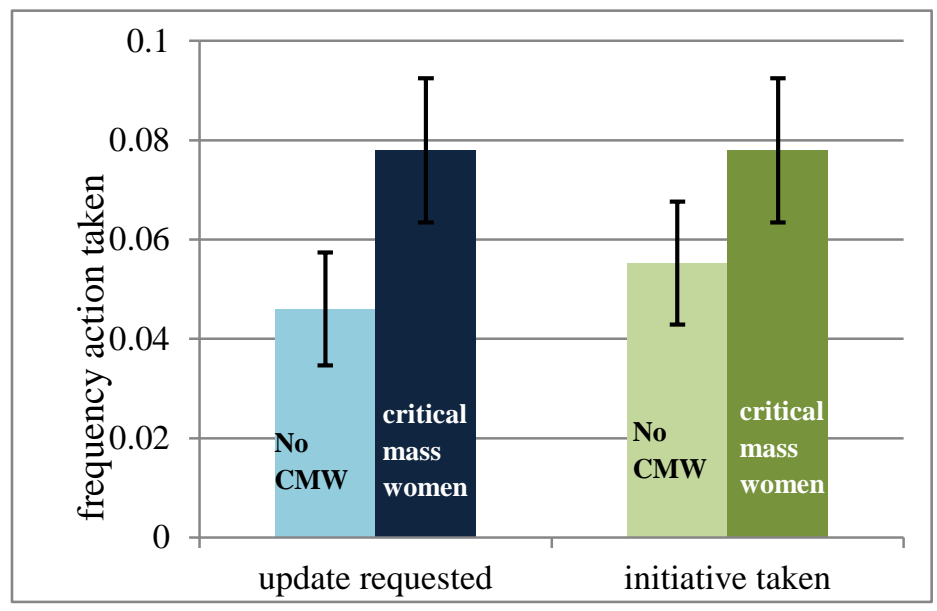

Figure 1e - Percentage of Cases Boards Requested to Receive Further Information or an Update

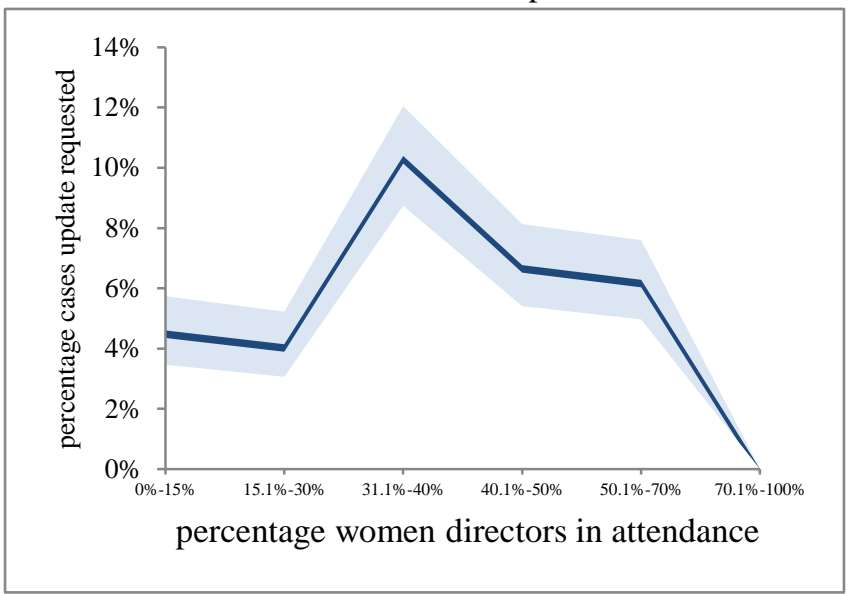

Figure 1d - Critical Masses of Men Directors and Frequency Action is Taken

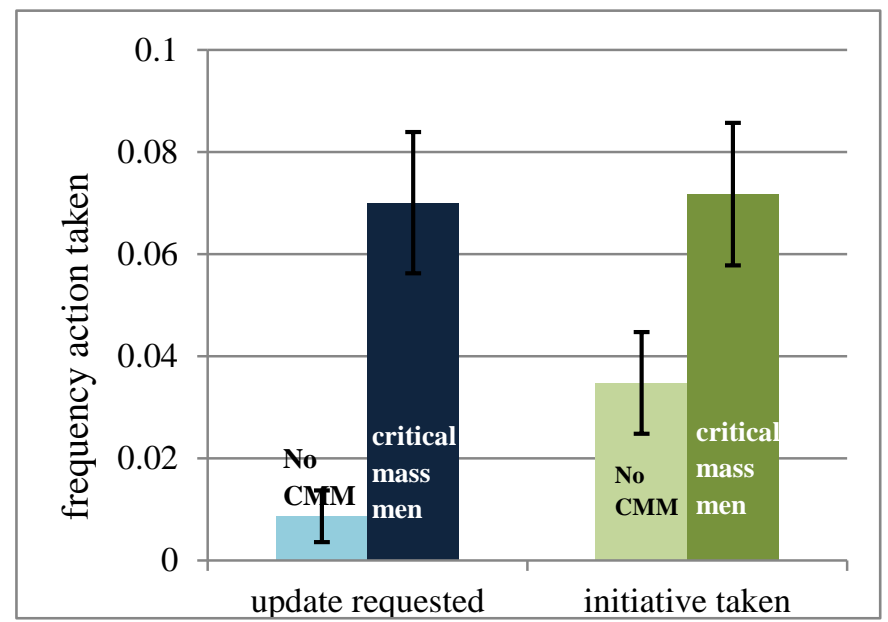

Figure 1f - Percentage of Cases Boards Took an Initiative

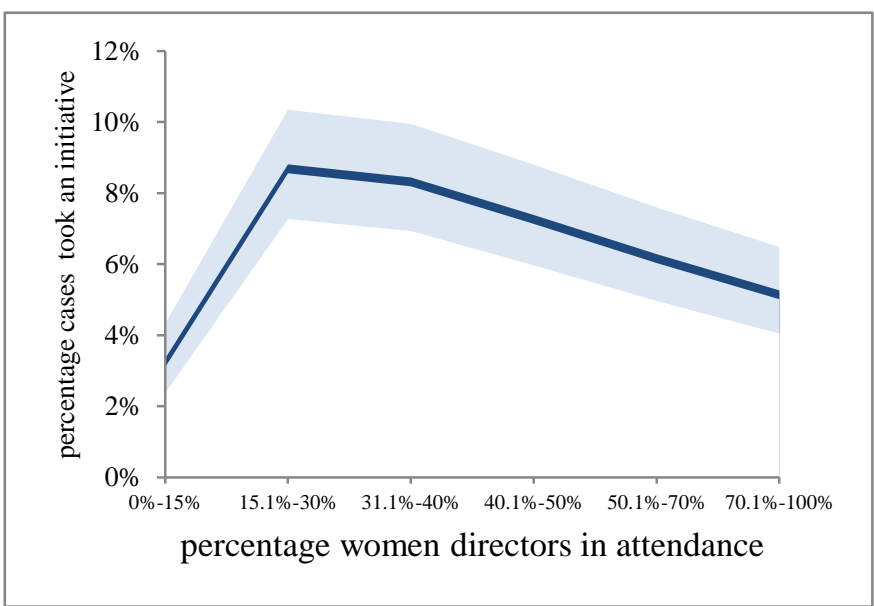

Figure 2

Critical Masses of Women Directors and Financial Performance

This figure reports the average return on equity (ROE) and net profit margin, of 34 GBCs, for the years 19972009. The figure is broken down depending on whether a board had a critical mass of at least three women directors in attendance. The error bars indicate the $95 \%$ confidence interval.

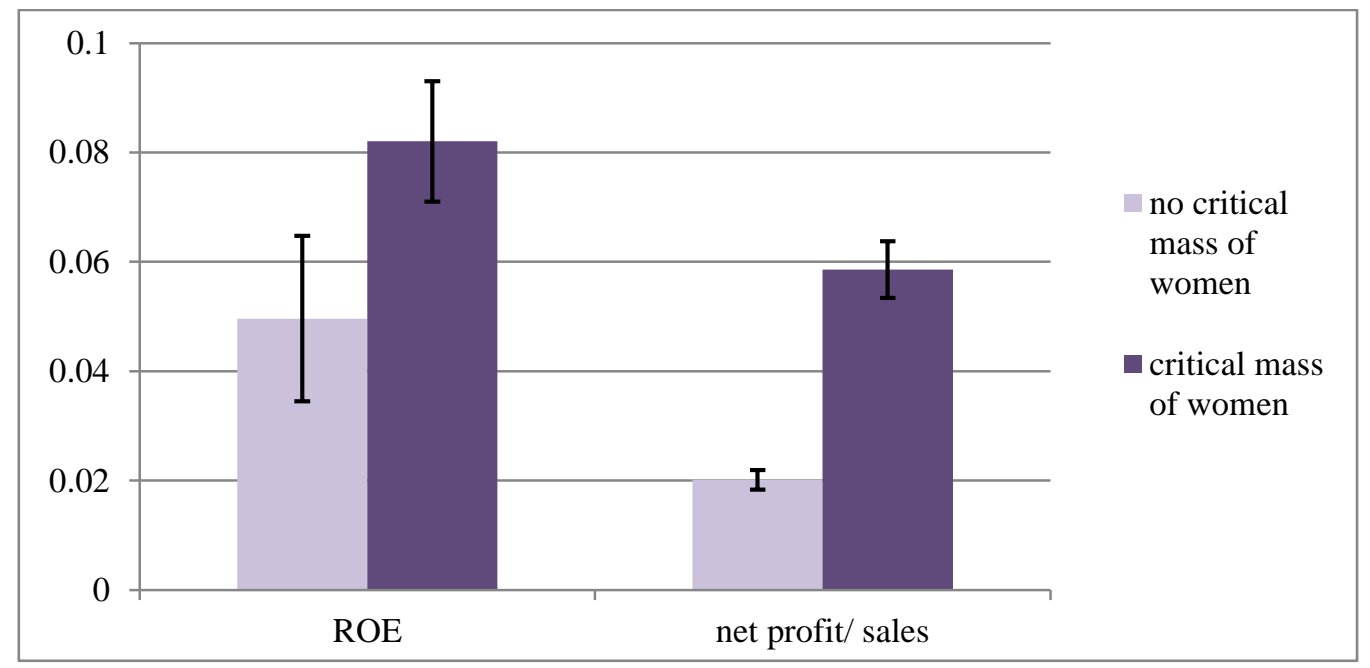


Figure 3

\section{The Gender of Directors and the Actions they Take}

This figure examines the likelihood that men and women directors of the eleven GBCs examined take action (either requesting further information or making an impact) with respect to a supervisory issue as opposed to a managerial one, as defined in Section 3.3.f. The figure reports only observations from board meetings for which no additional nomination mechanism prevails. The figure reports separately, for men and women, concerning all the actions they took, the percentage that pertained to supervisory issues and the percentage that pertained to managerial issues. Only actions that could be linked to a single director are reported in this figure.

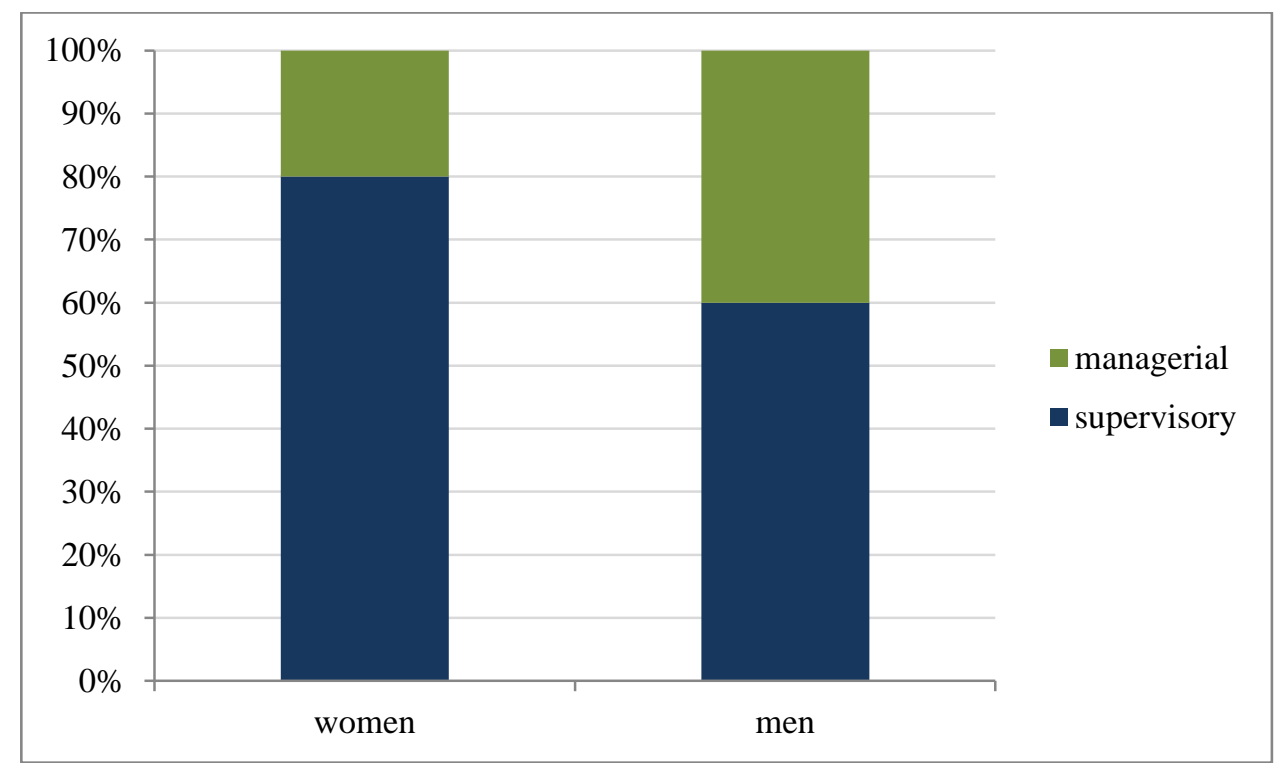

Figure 4

\section{Gender Composition and Length of Meetings}

This figure examines the impact of gender on the length of discussions in board-committees. The length of discussions for each of the board-committee meetings is standardized by dividing the number of pages of minutes of a particular board-committee meeting by the average number of pages of minutes of boardcommittee meetings for that particular firm. The shaded area indicates the $95 \%$ confidence interval.

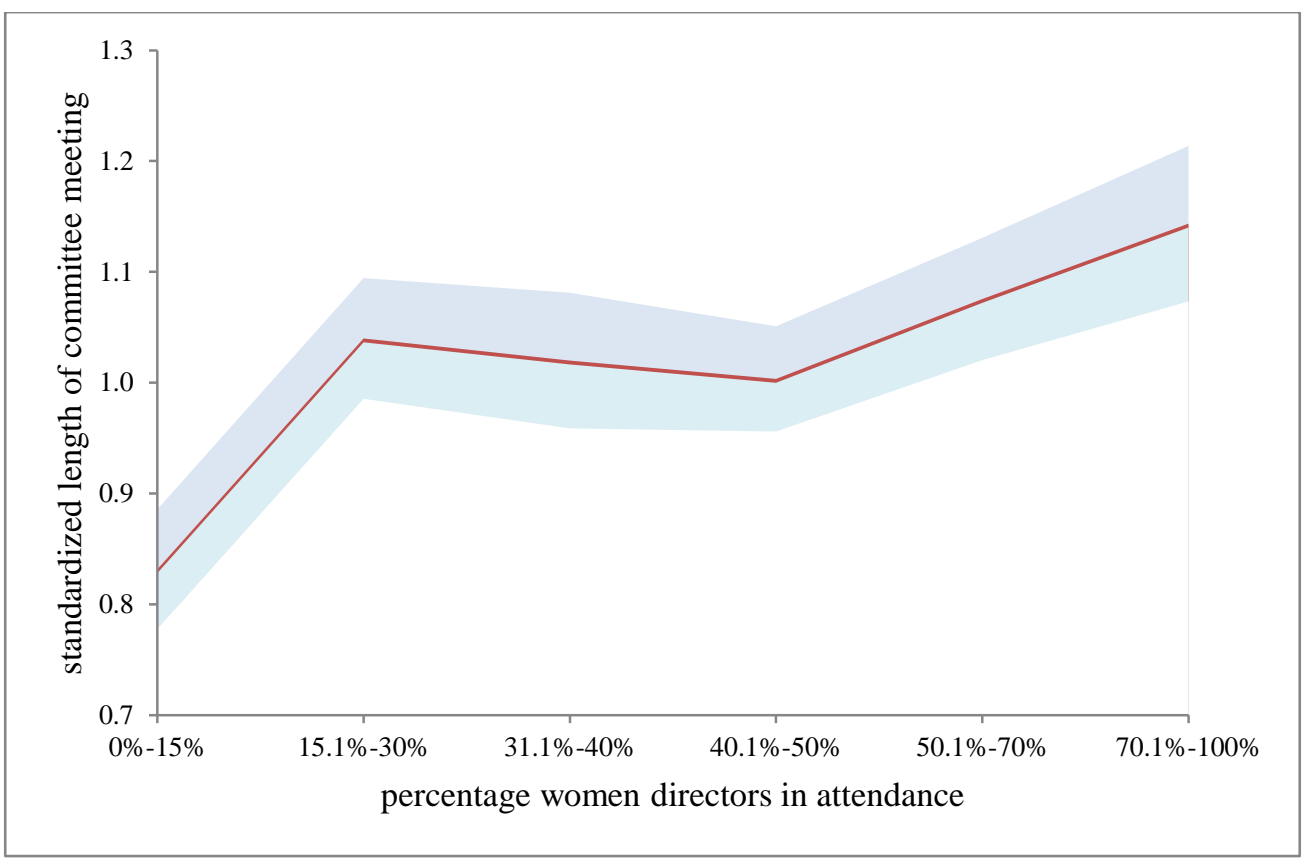


Table 1

Business Companies in Which the Israeli Government Holds Shares (GBCs)

This table reports 2007 figures for all GBCs. The data were taken from annual reports of the Government Companies Authority. ND indicates data is not available.

\begin{tabular}{|c|c|c|c|c|c|}
\hline & Name of company & $\begin{array}{l}\text { Annual } \\
\text { revenue in } \\
\text { thousands } \\
\text { of USD }\end{array}$ & $\begin{array}{c}\text { Number } \\
\text { of } \\
\text { employees }\end{array}$ & Field & $\begin{array}{l}\text { Percentage } \\
\text { held by the } \\
\text { government }\end{array}$ \\
\hline 1 & A.T. Communication Channels & 940 & 8 & Transportation and Communication & $100 \%$ \\
\hline 2 & Agrexco Agricultural Export Co. Ltd. & 868,460 & 365 & Agriculture & $50 \%$ \\
\hline 3 & Arim Urban Development Ltd. & 13,040 & 28 & Building, housing and Development & $100 \%$ \\
\hline 4 & Ashdod Port Company Ltd. & 263,670 & 1,275 & Transportation and Communication & $100 \%$ \\
\hline 5 & Ashot-Ashkelon Industries Ltd. & 56,120 & 399 & Defense & $88 \%$ \\
\hline 6 & Ashra the Israel Export Insurance Corporation & 12,440 & 18 & Industry and Commerce & $100 \%$ \\
\hline 7 & Atarim Tourist Development Corp. Tel Aviv Jaffa Ltd. & 6,140 & 23 & Industry and Commerce & $50 \%$ \\
\hline 8 & E.M.S. Ltd. & 83,130 & ND & Electricity and Water & $100 \%$ \\
\hline 9 & Eilat Port Company Ltd. & 27,380 & 112 & Transportation and Communication & $100 \%$ \\
\hline 10 & Elta Systems Ltd. & 918,750 & 3,407 & Defense & $100 \%$ \\
\hline 11 & Haifa Port Company Ltd. & 210,950 & 1,064 & Transportation and Communication & $100 \%$ \\
\hline 12 & Industrial Development Bank of Israel Ltd. & 26,580 & 43 & Industry and Commerce & $49 \%$ \\
\hline 13 & Insurance Fund for Natural Risks in Agriculture Ltd. & 46,000 & 69 & Agriculture & $50 \%$ \\
\hline 14 & Isorad Ltd. & 12,250 & 20 & Industry and Commerce & $100 \%$ \\
\hline 15 & Israel Aircraft Industries & $3,292,110$ & 12,939 & Defense & $100 \%$ \\
\hline 16 & Israel Bank of Agriculture & 9,780 & 25 & Agriculture & $92 \%$ \\
\hline 17 & Israel Government Coins and Medals Corporation Ltd. & 4,560 & 39 & Industry and Commerce & $100 \%$ \\
\hline 18 & Israel Military Industries Ltd. & 571,440 & 2,966 & Defense & $100 \%$ \\
\hline 19 & Israel Natural Gas Lines Company Ltd. & 7,970 & 69 & Energy and Petroleum & $100 \%$ \\
\hline 20 & Israel Ports Development and Assets Company Ltd. & 172,030 & 105 & Transportation and Communication & $100 \%$ \\
\hline 21 & Israel Postal Company Ltd. & 421,930 & 4,860 & Transportation and Communication & $100 \%$ \\
\hline 22 & Israel Railways Ltd. & 222,770 & 2,107 & Transportation and Communication & $100 \%$ \\
\hline 23 & Life Science Research Israel Ltd. & 4,820 & 47 & Industry and Commerce & $100 \%$ \\
\hline 24 & Matz - The Israel National ROEds Company Ltd. & 606,470 & 296 & Industry and Commerce & $100 \%$ \\
\hline 25 & Mekorot Water Co. Ltd. & 708,070 & 2,211 & Electricity and Water & $100 \%$ \\
\hline 26 & Oil Products Pipeline Ltd. & 20,050 & 0 & Energy and Petroleum & $100 \%$ \\
\hline 27 & Petroleum and Energy Infrastructures Ltd. & 75,750 & 383 & Energy and Petroleum & $100 \%$ \\
\hline 28 & Pi-Gliloth Petroleum Terminals and Pipelines Ltd. & 9,990 & 76 & Energy and Petroleum & $50 \%$ \\
\hline 29 & Postal Bank Company Ltd. & NA & 0 & Transportation and Communication & $100 \%$ \\
\hline 30 & Rafael Advanced Defense Systems & $1,286,160$ & 5,213 & Defense & $100 \%$ \\
\hline 31 & Rotem Industries Ltd. & 14,890 & 95 & Industry and Commerce & $100 \%$ \\
\hline 32 & The Israel Electric Corporation Ltd. & $4,689,390$ & 12,212 & Electricity and Water & $100 \%$ \\
\hline 33 & The Marine Trust Ltd. & 6,240 & 8 & Building, Housing and Development & $50 \%$ \\
\hline 34 & The National Coal Supply Corporation Ltd. & $1,069,140$ & 26 & Electricity and Water & $99 \%$ \\
\hline
\end{tabular}


Table 2

\section{Representativeness of Sample}

This table compares the background of the directors serving on the boards of the eleven GBCs for which minutes were examined to the background of directors serving on boards of other types of companies.

Average age

Have executive experience^

Have undergraduate degree

Have an MA/ MBA degree

Served or are serving on other boards

Of these: non govt./ non-NGO boards

Currently on a board of a listed company

Number of directors

Percent of each gender

\section{Year examined}

Number of companies examined

Source from which data was obtained / used

to calculate figure

\begin{tabular}{c|c}
\multicolumn{2}{c}{ GBCs } \\
\hline $\begin{array}{c}\text { Women } \\
\text { directors }\end{array}$ & $\begin{array}{c}\text { Men } \\
\text { directors }\end{array}$ \\
\hline 49.3 & $\mathbf{5 2 . 5}$ \\
$52 \%$ & $62 \%$ \\
$100 \%$ & $94 \%$ \\
$56 \%$ & $44 \%$ \\
$45 \%$ & $44 \%$ \\
$18 \%$ & $22 \%$ \\
ND & ND \\
50 & 86 \\
$37 \%$ & $63 \%$ \\
\hline \multicolumn{2}{|c}{2008} \\
\hline
\end{tabular}

11

GCA database
Public Israeli

\begin{tabular}{cc}
\hline Women & Men \\
directors & directors \\
\hline
\end{tabular}

directors directors

\begin{tabular}{c|c}
\hline 51 & 59 \\
$79 \%$ & $94 \%$ \\
$90 \%$ & $86 \%$ \\
$85 \%$ & $78 \%$ \\
ND & ND \\
ND & ND \\
$17 \%$ & $18 \%$ \\
684 & 3020 \\
$18 \%$ & $82 \%$ \\
\hline \multicolumn{2}{c}{2009}
\end{tabular}

100

Israeli Stock Exchange Authority, 2010

\begin{tabular}{cc}
\multicolumn{2}{c}{ Public Norwegian } \\
\hline $\begin{array}{c}\text { Women } \\
\text { directors }\end{array}$ & $\begin{array}{c}\text { Men } \\
\text { directors }\end{array}$ \\
\hline 46 & 51 \\
$51 \%$ & $61 \%$ \\
$56 \%$ & $46 \%$ \\
$24 \%$ & $22 \%$ \\
ND & ND \\
ND & ND \\
$17 \% \wedge \wedge$ & $19 \% \wedge \wedge$ \\
249 & 383 \\
$39 \%$ & $61 \%$ \\
\hline \multicolumn{2}{c}{2009}
\end{tabular}

113

Ahern and Dittmar, 2011

\begin{tabular}{cc}
\multicolumn{2}{c}{ Public Swiss } \\
\hline $\begin{array}{c}\text { Women } \\
\text { directors }\end{array}$ & $\begin{array}{c}\text { Men } \\
\text { directors }\end{array}$ \\
\hline ND & ND \\
$3 \%$ & $18 \%$ \\
$91 \%$ & $95 \%$ \\
$79 \%$ & $84 \%$ \\
ND & ND \\
ND & ND \\
$18 \%$ & $31 \%$ \\
50 & 1628 \\
$3 \%$ & $97 \%$ \\
\hline \multicolumn{2}{c}{2003}
\end{tabular}

269

Ruigrok et al., 2007

\begin{tabular}{cc}
\multicolumn{2}{c}{ American S\&P 500 } \\
\hline $\begin{array}{c}\text { Women } \\
\text { directors }\end{array}$ & $\begin{array}{c}\text { Men } \\
\text { directors }\end{array}$ \\
\hline $56^{\wedge \wedge \wedge}$ & $60^{\wedge \wedge \wedge}$ \\
$56 \%$ & $67 \%$ \\
ND & ND \\
ND & ND \\
ND & ND \\
ND & ND \\
$24 \% \wedge \wedge \wedge$ & $21 \% \wedge \wedge$ \\
ND & ND \\
$16 \%$ & $84 \%$ \\
\hline \multicolumn{2}{c}{2011} \\
\multicolumn{3}{c}{500}
\end{tabular}

Spencer Stuart US Board Index, 2011

$\wedge$ In most studies, executive experience is defined as having been a CEO or held an executive position in an organization - e.g., head of a functional unit, partner/principal, or vice president. However, definitions vary among studies.

$\wedge \wedge$ Figures pertain only to directors whose primary occupation is serving as directors.

$\wedge \wedge \wedge$ Figure from Peterson and Philpot (2007), pertains to 2002 Fortune 500 boards. 
Table 3

Summary Statistics on Minutes-data

This table reports summary statistics on the minutes of the eleven GBCs for which minutes were examined.

\begin{tabular}{|c|c|c|c|}
\hline & $\begin{array}{c}\text { Board } \\
\text { meetings }\end{array}$ & $\begin{array}{c}\text { Board- } \\
\text { committee } \\
\text { meetings }\end{array}$ & $\begin{array}{c}\text { Board and } \\
\text { board- } \\
\text { committee } \\
\text { meetings }\end{array}$ \\
\hline \multicolumn{4}{|l|}{ Board composition in attendance } \\
\hline Average number of directors in attendance & 8.1 & 4.3 & 6.38 \\
\hline Average percentage of attending directors who are women & $36 \%$ & $37 \%$ & $37 \%$ \\
\hline Average percentage of attending directors who are men & $64 \%$ & $71 \%$ & $67 \%$ \\
\hline Percentage of cases with at least three women in attendance & $58 \%$ & $28 \%$ & $45 \%$ \\
\hline Percentage of cases with at least three men in attendance & $91 \%$ & $53 \%$ & $73 \%$ \\
\hline Percentage of cases with at least three direc. of each gender & $51 \%$ & $16 \%$ & $35 \%$ \\
\hline \multicolumn{4}{|l|}{ Actions taken by the boards } \\
\hline Average percentage of cases an update was requested & $6.4 \%$ & $17.1 \%$ & $11.3 \%$ \\
\hline Average percentage of cases an impact was made & $6.8 \%$ & $12.1 \%$ & $9.3 \%$ \\
\hline Average percentage of cases update requested or impact made & $12.4 \%$ & $25.7 \%$ & $18.6 \%$ \\
\hline \multicolumn{4}{|l|}{ Sample size } \\
\hline Number of companies examined & 11 & 9 & \\
\hline Average number of meetings per company & 14.1 & 27.4 & \\
\hline Median number of meetings per company & 12 & 18 & \\
\hline Average number of issues discussed per meeting & 8.5 & 4.6 & 6.1 \\
\hline Total number of meetings examined & 155 & 247 & 402 \\
\hline Total number of issues discussed (cases) & 1313 & 1146 & 2459 \\
\hline Average number of pages of minutes per meeting & 14.2 & 10.3 & 11.8 \\
\hline Total number of pages of minutes & 2204 & 2554 & 4758 \\
\hline
\end{tabular}


Table 4

\section{Summary Statistics on Board Activity}

This table reports the 1313 issues discussed in board meetings by the boards of the eleven GBCs examined, broken down by the topic-subject discussed. Columns 1-2 report the average percentage of cases in which the board requested further information or an update, broken down according to whether a dual-critical mass of three directors of each gender was (Column 1) or was not (Column 2) in attendance. Columns 3-4 report the average percentage of cases in which boards made an impact (e.g., suggested which action be taken), broken down according to whether a dual-critical mass of three directors of each gender was (Column 3) or was not (Column 4) in attendance.

\begin{tabular}{|c|c|c|c|c|c|}
\hline & \multicolumn{2}{|c|}{$\underline{\text { Update requested }}$} & \multicolumn{2}{|c|}{ Impact made } & \multirow{3}{*}{$\begin{array}{c}\text { Total } \\
\text { number } \\
\text { of cases } \\
(5)\end{array}$} \\
\hline & $\begin{array}{c}\text { Dual } \\
\text { critical } \\
\text { mass }\end{array}$ & $\begin{array}{l}\text { No dual } \\
\text { critical } \\
\text { mass }\end{array}$ & $\begin{array}{l}\text { Dual } \\
\text { critical } \\
\text { mass }\end{array}$ & $\begin{array}{c}\text { No dual } \\
\text { critical } \\
\text { mass }\end{array}$ & \\
\hline & $(1)$ & (2) & (3) & (4) & \\
\hline Audit & $23.5 \%$ & $0.0 \%$ & $17.6 \%$ & $4.8 \%$ & 38 \\
\hline Contracting/ purchases & $10.0 \%$ & $6.1 \%$ & $10.0 \%$ & $18.2 \%$ & 83 \\
\hline Legal & $11.8 \%$ & $10.3 \%$ & $23.5 \%$ & $0.0 \%$ & 46 \\
\hline Ratification of audit committee & $0.0 \%$ & $0.0 \%$ & $0.0 \%$ & $0.0 \%$ & 8 \\
\hline Total audit and contracting & $12.9 \%$ & $5.6 \%$ & $14.1 \%$ & $7.8 \%$ & 175 \\
\hline Business issues & $11.1 \%$ & $5.7 \%$ & $7.2 \%$ & $3.3 \%$ & 417 \\
\hline Business projects & $14.5 \%$ & $13.9 \%$ & $7.2 \%$ & $5.6 \%$ & 105 \\
\hline Cross-firm issues & $22.2 \%$ & $5.3 \%$ & $18.5 \%$ & $5.3 \%$ & 46 \\
\hline Investment/ finance & $2.6 \%$ & $0.0 \%$ & $7.9 \%$ & $6.5 \%$ & 69 \\
\hline Ongoing general issues & $5.8 \%$ & $4.4 \%$ & $0.0 \%$ & $0.0 \%$ & 120 \\
\hline Ratification of operational comm. & $0.0 \%$ & $0.0 \%$ & $0.0 \%$ & $12.5 \%$ & 9 \\
\hline Regulation and government & $6.7 \%$ & $2.1 \%$ & $8.9 \%$ & $4.2 \%$ & 93 \\
\hline Strategic issues & $12.5 \%$ & $25.0 \%$ & $12.5 \%$ & $25.0 \%$ & 12 \\
\hline Total business issue & $11.1 \%$ & $5.7 \%$ & $7.2 \%$ & $3.3 \%$ & 417 \\
\hline Budget & $25.0 \%$ & $5.7 \%$ & $8.3 \%$ & $2.9 \%$ & 71 \\
\hline Business projects & $14.5 \%$ & $13.9 \%$ & $7.2 \%$ & $5.6 \%$ & 105 \\
\hline Financial reports & $17.1 \%$ & $9.4 \%$ & $8.6 \%$ & $9.4 \%$ & 67 \\
\hline Investment/ finance & $2.6 \%$ & $0.0 \%$ & $7.9 \%$ & $6.5 \%$ & 69 \\
\hline Ongoing general issues & $5.8 \%$ & $4.4 \%$ & $0.0 \%$ & $0.0 \%$ & 120 \\
\hline Ratification of financial comm. & $0.0 \%$ & $0.0 \%$ & $0.0 \%$ & $0.0 \%$ & 10 \\
\hline Total financial issues & $14.2 \%$ & $4.8 \%$ & $8.0 \%$ & $5.7 \%$ & 218 \\
\hline Appointment of members & $0.0 \%$ & $0.0 \%$ & $0.0 \%$ & $11.8 \%$ & 47 \\
\hline Approving past minutes & $0.0 \%$ & $0.0 \%$ & $0.0 \%$ & $0.0 \%$ & 83 \\
\hline Choosing chairman for meeting & $0.0 \%$ & $0.0 \%$ & $0.0 \%$ & $0.0 \%$ & 31 \\
\hline Financial reports & $17.1 \%$ & $9.4 \%$ & $8.6 \%$ & $9.4 \%$ & 67 \\
\hline Formal issues & $0.0 \%$ & $0.0 \%$ & $0.9 \%$ & $1.8 \%$ & 224 \\
\hline Total formal issues & $0.0 \%$ & $0.0 \%$ & $0.9 \%$ & $1.8 \%$ & 224 \\
\hline Appointing/ firing an executive & $0.0 \%$ & $0.0 \%$ & $37.5 \%$ & $30.0 \%$ & 54 \\
\hline Organizational changes & $0.0 \%$ & $0.0 \%$ & $7.7 \%$ & $0.0 \%$ & 17 \\
\hline Personnel and benefits & $6.4 \%$ & $2.4 \%$ & $12.2 \%$ & $9.8 \%$ & 279 \\
\hline Ratification of HR committee & $0.0 \%$ & $0.0 \%$ & $0.0 \%$ & $0.0 \%$ & 30 \\
\hline Total personnel and benefits & $6.4 \%$ & $2.4 \%$ & $12.2 \%$ & $9.8 \%$ & 279 \\
\hline Total & $8.9 \%$ & $3.9 \%$ & $8.3 \%$ & $5.3 \%$ & 1313 \\
\hline
\end{tabular}


Table 5

\section{Gender Composition and Board Activeness}

This table reports OLS regressions analyzing the issues discussed at board-and/or board-committee meetings by the boards of the eleven GBCs examined. The dependent variable is a binary variable that equals one if the board requested to receive further information or an update or, in alternative specifications, it took an initiative (e.g., suggested which action should be taken). The primary independent variables are the fraction of attending women directors and its square, a dummy which equals one when at least three women directors were in attendance, a dummy which equals one when at least three men directors were in attendance, and a dummy that equals one if at least three directors of each gender were in attendance. In addition, the regressions control for the fraction of attending outside directors, the total number of attending directors, the average number of years of executive experience of the attending directors, the fraction of attending directors with an MA/MBA, a dummy that equals one if the firm was in the process of replacing the CEO, and a dummy that equals one if the issue discussed was one of supervisory nature as described in Section 3.3.f. For each variable, the first line reports the coefficient and the second line (in round parentheses) reports clustered errors at meeting level. $* * *, * *, *$, indicate significance at the $0.01,0.05$, and the 0.10 level, respectively.

\begin{tabular}{|c|c|c|c|c|c|c|}
\hline & $\begin{array}{l}\text { Update } \\
\text { requested }\end{array}$ & $\begin{array}{c}\text { Initiative } \\
\text { taken }\end{array}$ & $\begin{array}{c}\text { Update } \\
\text { requested }\end{array}$ & $\begin{array}{l}\text { Initiative } \\
\text { taken }\end{array}$ & $\begin{array}{l}\text { Impact or } \\
\text { update }\end{array}$ & $\begin{array}{l}\text { Update or } \\
\text { initiative }\end{array}$ \\
\hline & (1) & (2) & (3) & (4) & (5) & (6) \\
\hline $\begin{array}{l}\text { Fraction of women directors } \\
\text { in attendance }\end{array}$ & $\begin{array}{l}-.012 \\
(.175)\end{array}$ & $\begin{array}{l}-.210 \\
(.186)\end{array}$ & & & & \\
\hline $\begin{array}{l}\text { Square of fraction of women } \\
\text { directors in attendance }\end{array}$ & $\begin{array}{l}.027 \\
(.167)\end{array}$ & $\begin{array}{l}.245 \\
(.196)\end{array}$ & & & & \\
\hline $\begin{array}{l}\text { Three or more women } \\
\text { directors in attendance }\end{array}$ & & & $\begin{array}{c}.063^{* * *} \\
(.022)\end{array}$ & $\begin{array}{c}.087 * * * \\
(.031)\end{array}$ & $\begin{array}{c}.125^{* * * *} \\
(.040)\end{array}$ & \\
\hline $\begin{array}{l}\text { Three or more men directors } \\
\text { in attendance }\end{array}$ & & & $\begin{array}{c}.030 * * * \\
(.019)\end{array}$ & $\begin{array}{l}.036 \\
(.024)\end{array}$ & $\begin{array}{l}.051 * \\
(.030)\end{array}$ & \\
\hline $\begin{array}{l}\text { Critical masses of both } \\
\text { genders }\end{array}$ & & & & & & $\begin{array}{c}.102 * * * \\
(.03)\end{array}$ \\
\hline $\begin{array}{l}\text { Fraction of outsiders in } \\
\text { attendance }\end{array}$ & $\begin{array}{l}-.010 \\
(.033)\end{array}$ & $\begin{array}{l}.003 \\
(.033)\end{array}$ & $\begin{array}{l}.019 \\
(.034)\end{array}$ & $\begin{array}{l}.039 \\
(.037)\end{array}$ & $\begin{array}{l}.030 \\
(.054)\end{array}$ & $\begin{array}{l}.002 \\
(.049)\end{array}$ \\
\hline $\begin{array}{l}\text { Number of directors in } \\
\text { attendance }\end{array}$ & $\begin{array}{l}-.000 \\
(.005)\end{array}$ & $\begin{array}{l}.010^{* *} \\
(0.005)\end{array}$ & $\begin{array}{l}-.003 \\
(.005)\end{array}$ & $\begin{array}{l}.005 \\
(.004)\end{array}$ & $\begin{array}{l}.001 \\
(.008)\end{array}$ & $\begin{array}{l}.000 \\
(.008)\end{array}$ \\
\hline Average executive experience & $\begin{array}{l}.011^{*} \\
(.007)\end{array}$ & $\begin{array}{l}-.004 \\
(.004)\end{array}$ & $\begin{array}{l}.011 * * \\
(.006)\end{array}$ & $\begin{array}{l}-.004 \\
(.004)\end{array}$ & $\begin{array}{l}.005 \\
(.008)\end{array}$ & $\begin{array}{l}.002 \\
(.008)\end{array}$ \\
\hline Average MA/MBA & $\begin{array}{l}-.069 \\
(.073)\end{array}$ & $\begin{array}{l}.077 \\
(.064)\end{array}$ & $\begin{array}{l}-.055 \\
(.071)\end{array}$ & $\begin{array}{l}.084 \\
(.057)\end{array}$ & $\begin{array}{l}.033 \\
(.096)\end{array}$ & $\begin{array}{l}.030 \\
(.096)\end{array}$ \\
\hline Between CEOs & $\begin{array}{l}-.021 \\
(.039)\end{array}$ & $\begin{array}{l}.050 \\
(.036)\end{array}$ & $\begin{array}{l}-.022 \\
(.034)\end{array}$ & $\begin{array}{l}.044 \\
(.026)\end{array}$ & $\begin{array}{l}.034 \\
(.046)\end{array}$ & $\begin{array}{l}.039 \\
(.047)\end{array}$ \\
\hline Supervisory issue & $\begin{array}{c}-.093 * * \\
(.043)\end{array}$ & $\begin{array}{l}.062 * * \\
(.027)\end{array}$ & $\begin{array}{c}-.052 \\
(.042)\end{array}$ & $\begin{array}{c}.128 * * * \\
(.033)\end{array}$ & $\begin{array}{c}.062 \\
(.055)\end{array}$ & $\begin{array}{c}.039 \\
(.047)\end{array}$ \\
\hline Firm and year dummies & Yes & Yes & Yes & Yes & Yes & Yes \\
\hline Topic-subject dummies & Yes & Yes & Yes & Yes & Yes & Yes \\
\hline Number of observations & 1313 & 1313 & 1313 & 1313 & 1313 & 1313 \\
\hline F probability & .000 & .000 & .000 & .000 & .000 & .000 \\
\hline $\mathrm{R}$ squared & .086 & .101 & 0.093 & 0.108 & .115 & .114 \\
\hline
\end{tabular}


Table 6

\section{Gender Composition and Board Activeness - 2SLS Analysis}

This table reports results of a 2SLS model analyzing the 1313 issues discussed at board meetings by the boards of the eleven GBCs examined. The model instruments for the likelihood that a critical mass of at least three women directors, and one of at least three men directors, will attend a particular board meeting in which a particular issue is discussed, using an instrument variable that equals the number of women directors that were invited to at least one board-committee meeting on the same day a particular issue was discussed at the board meeting, and a parallel variable for men directors. Regressions 1-2 report the first-stage regressions of the 2SLS analyses reported in Regressions 3-5. The dependent variable is a binary variable that equals one if the board requested to receive further information or an update (Regression 3), took an initiative such as suggesting which action should be taken (Regression 4), or either requested an update or took an initiative (Regression 5-6). The regressions control for the following control variables (not reported): the fraction of attending outside directors, the total number of attending directors, the average number of years of executive experience of the attending directors, the fraction of attending directors with an MA/MBA, a dummy that equals one if the firm was in the process of replacing the CEO, and a dummy that equals one if the issue discussed was one of supervisory nature as described in Section 3.3.f. For each variable, the first line reports the coefficient and the second line reports (in round parentheses) errors. ***, **, *, indicate significance at the $0.01,0.05$, and the 0.10 level, respectively.

\begin{tabular}{|c|c|c|c|c|c|c|}
\hline & $\begin{array}{c}\text { Three or } \\
\text { more women } \\
\text { in attendance } \\
(1)\end{array}$ & $\begin{array}{c}\text { Three or } \\
\text { more men in } \\
\text { attendance } \\
(2) \\
\end{array}$ & $\begin{array}{c}\text { Update } \\
\text { requested } \\
\text { (3) }\end{array}$ & $\begin{array}{l}\text { Initiative } \\
\text { taken } \\
(4)\end{array}$ & $\begin{array}{c}\text { Update or } \\
\text { initiative } \\
(5)\end{array}$ & $\begin{array}{c}\text { Update or } \\
\text { initiative } \\
(6)\end{array}$ \\
\hline $\begin{array}{l}\text { Number of women invited } \\
\text { to board-committee }\end{array}$ & $\begin{array}{l}.061 * * * \\
(.006)\end{array}$ & $\begin{array}{c}-.015 * * * \\
(.005)\end{array}$ & & & & \\
\hline $\begin{array}{l}\text { Number of men invited to } \\
\text { board-committee }\end{array}$ & $\begin{array}{c}-.017 * * * \\
(.005)\end{array}$ & $\begin{array}{c}.017 * * * \\
(.004)\end{array}$ & & & & \\
\hline $\begin{array}{l}\text { Three or more women } \\
\text { directors in attendance }\end{array}$ & & & $\begin{array}{l}.241 * * \\
(.122)\end{array}$ & $\begin{array}{c}.338 * * * \\
(.128)\end{array}$ & $\begin{array}{l}.561 * * * \\
(.201)\end{array}$ & \\
\hline $\begin{array}{l}\text { Three or more men directors } \\
\text { in attendance }\end{array}$ & & & $\begin{array}{l}.576 \\
(.370)\end{array}$ & $\begin{array}{l}.659 * \\
(.389)\end{array}$ & $\begin{array}{l}1.401 * * \\
(.6108)\end{array}$ & \\
\hline $\begin{array}{l}\text { Critical masses of both } \\
\text { genders }\end{array}$ & & & & & & $\begin{array}{c}.558 * * * \\
(.160)\end{array}$ \\
\hline Board control variables & Yes & Yes & Yes & Yes & Yes & Yes \\
\hline Year and firm dummies & Yes & Yes & Yes & Yes & Yes & Yes \\
\hline Topic-subject dummies & Yes & Yes & Yes & Yes & Yes & Yes \\
\hline 2SLS equation estimated & First stage & First stage & 2SLS & 2SLS & 2SLS & 2SLS \\
\hline Number of observations & 1,313 & 1,313 & 1,313 & 1,313 & 1,313 & 1,313 \\
\hline $\mathrm{R}$ square & .712 & .369 & & & & \\
\hline Angrist-Pischke F-test & 66.38 & 10.01 & & & & \\
\hline Significance & .000 & .000 & .000 & .000 & .000 & .000 \\
\hline \multicolumn{3}{|c|}{$\begin{array}{l}\text { Sargan statistic-over identifying test } \\
\text { (p-value) }\end{array}$} & $\begin{array}{c}2.55 \\
(.999)\end{array}$ & $\begin{array}{l}2.45 \\
(.999)\end{array}$ & $\begin{array}{c}3.81 \\
(.999) \\
1.45 \\
(.234)\end{array}$ & $\begin{array}{c}8.02 \\
(.999)\end{array}$ \\
\hline
\end{tabular}


Table 7

\section{Gender Composition and Financial Performance}

This table reports OLS regressions analyzing a panel data set of the universe of the 34 GBCs, for the years 19972009. The dependent variable is ROE (Regressions 1-3) or alternatively, net profit margin, i.e., net profit divided by sales (Regressions 4-6). The primary independent variables are the fraction of women directors appointed to the board and its square, a dummy which equals one in cases in which at least three women directors were appointed, and a dummy which equals one in cases in which at least three men directors were appointed. In addition, the regressions control for the fraction of outsiders appointed, the total number of directors appointed and the tenure of the CEO. Year and firm dummies are included as specified. For each variable, the first line reports the coefficient and the second line reports (in round parentheses) clustered errors at meeting level. $* * *, * *$, , indicate significance at the $0.01,0.05$, and 0.10 level, respectively.

\begin{tabular}{|c|c|c|c|c|c|c|}
\hline \multirow[b]{3}{*}{ Fraction of women appointed } & \multicolumn{3}{|c|}{ ROE (\%) } & \multicolumn{3}{|c|}{ net profit / sales (\%) } \\
\hline & (1) & (2) & (3) & (4) & (5) & (6) \\
\hline & $\begin{array}{l}-.060 \\
(.077)\end{array}$ & & & $\begin{array}{l}.121 \\
(.187)\end{array}$ & & \\
\hline $\begin{array}{l}\text { Square of fraction of women } \\
\text { appointed }\end{array}$ & $\begin{array}{l}.120 \\
(.060)\end{array}$ & & & $\begin{array}{l}.001 \\
(.167)\end{array}$ & & \\
\hline $\begin{array}{l}\text { Three or more women directors } \\
\text { appointed }\end{array}$ & & $\begin{array}{c}.032 * * * \\
(.003)\end{array}$ & $\begin{array}{l}.012 * \\
(.004)\end{array}$ & & $\begin{array}{l}.048 * * \\
(.013)\end{array}$ & $\begin{array}{l}.040 * * \\
(.010)\end{array}$ \\
\hline $\begin{array}{l}\text { Three or more men directors } \\
\text { appointed }\end{array}$ & & $\begin{array}{c}.047 * * * \\
(.007)\end{array}$ & $\begin{array}{l}.007 \\
(.012)\end{array}$ & & $\begin{array}{l}.003 \\
(.014)\end{array}$ & $\begin{array}{l}.020 \\
(.000)\end{array}$ \\
\hline Fraction of outsiders appointed & $\begin{array}{c}.081 * * * \\
(.004)\end{array}$ & $\begin{array}{l}.016 \\
(.023)\end{array}$ & $\begin{array}{c}.078 * * * \\
(.007)\end{array}$ & $\begin{array}{c}.178^{* * *} \\
(.023)\end{array}$ & $\begin{array}{l}.119 * * \\
(.032)\end{array}$ & $\begin{array}{l}.175^{* * * *} \\
(.000)\end{array}$ \\
\hline Number of directors appointed & $\begin{array}{l}.004 \\
(.002)\end{array}$ & $\begin{array}{l}-.000 \\
(.001)\end{array}$ & $\begin{array}{l}.002 \\
(.002)\end{array}$ & $\begin{array}{c}-.008 * * * \\
(.000)\end{array}$ & $\begin{array}{l}-.011 \\
(.001)\end{array}$ & $\begin{array}{l}-.014 \\
(.000)\end{array}$ \\
\hline Tenure of CEO & $\begin{array}{l}.005 \\
(.004)\end{array}$ & $\begin{array}{l}.001 \\
(.001)\end{array}$ & $\begin{array}{l}.004 \\
(.004)\end{array}$ & $\begin{array}{l}.004 \\
(.003)\end{array}$ & $\begin{array}{c}.004 \\
(.001)\end{array}$ & $\begin{array}{l}.003 \\
(.002)\end{array}$ \\
\hline Firm and year dummies & Yes & No & Yes & Yes & No & Yes \\
\hline Number of observations & 288 & 288 & 288 & 311 & 311 & 311 \\
\hline F probability & .000 & .000 & .000 & .000 & .000 & .000 \\
\hline R-squared & .455 & .023 & .453 & .437 & .079 & 041 \\
\hline
\end{tabular}


Table 8

\section{Gender Composition and Likelihood that Women and Men Directors Take Action}

This table reports OLS regressions analyzing the 1313 issues (cases) the eleven GBC boards examined discussed at board meetings. The regressions examine separately the likelihood that women directors take action (Regressions 13 ) and that men director take one (Regressions 4-6). Because usually women directors constitute a smaller fraction of all attending directors, (using the Horvitz-Thompson estimator) the dependent variable in Regressions 1-2 and 4-5 is calculated to represent the adjusted likelihood that a woman or a man director will take an action, given the fraction of their gender out of all attending directors. In Regressions 3 and 6 the dependent variable is a binary variable that equals one if an action was taken by a woman director (Regression 3), or if an action was taken by a man director (Regression 6). The primary independent variables are the fraction of attending women directors and its square, a dummy which equals one in cases in which at least three women directors were in attendance, and a dummy which equals one in cases in which at least three men directors were in attendance. In addition, the regressions control for the fraction of attending outside directors, number of attending directors, average number of years of executive experience of the attending directors, fraction of attending directors with an MA/MBA, a dummy which equals one if the firm was in the process of replacing the $\mathrm{CEO}$ at the time the issue was discussed, and a dummy which equals one if the issue discussed was a supervisory one as described in Section 3.3.f. For each variable, the first line reports the coefficient and the second line reports (in round parentheses) clustered errors at meeting level. ***,**, *, indicate significance at the $0.01,0.05$, and the 0.10 level, respectively.

\begin{tabular}{|c|c|c|c|c|c|c|}
\hline & \multicolumn{3}{|c|}{ Women directors } & \multicolumn{3}{|c|}{ Men directors } \\
\hline & \multicolumn{2}{|c|}{ Adjusted likelihood action } & \multirow{2}{*}{$\begin{array}{c}\text { Action } \\
(3)\end{array}$} & \multicolumn{2}{|c|}{ Adjusted likelihood action } & \multirow{2}{*}{$\begin{array}{c}\text { Action } \\
(6)\end{array}$} \\
\hline & (1) & (2) & & (4) & (5) & \\
\hline Fraction of women & $\begin{array}{l}.143 \\
(.151)\end{array}$ & & & $\begin{array}{l}-.130 \\
(.145)\end{array}$ & & \\
\hline Square of fraction of women & $\begin{array}{l}-.093 \\
(.146)\end{array}$ & & & $\begin{array}{l}.176 \\
(.156)\end{array}$ & & \\
\hline $\begin{array}{l}\text { Three or more women directors } \\
\text { in attendance }\end{array}$ & & $\begin{array}{c}.056^{* * *} \\
(.018)\end{array}$ & $\begin{array}{l}.045^{* * * *} \\
(.013)\end{array}$ & & $\begin{array}{l}.039 * * \\
(.018)\end{array}$ & $\begin{array}{l}.036^{*} \\
(.021)\end{array}$ \\
\hline $\begin{array}{l}\text { Three or more men directors in } \\
\text { attendance }\end{array}$ & & $\begin{array}{l}.010 \\
(.012)\end{array}$ & $\begin{array}{l}.012 \\
(.013)\end{array}$ & & $\begin{array}{l}.007 \\
(.030)\end{array}$ & $\begin{array}{l}.013 \\
(.023)\end{array}$ \\
\hline Fraction of outsiders & $\begin{array}{l}-.020 \\
(.017)\end{array}$ & $\begin{array}{l}.040 \\
(.021)\end{array}$ & $\begin{array}{l}.027 \\
(.016)\end{array}$ & $\begin{array}{l}.000 \\
(.002)\end{array}$ & $\begin{array}{l}.010 \\
(.033)\end{array}$ & $\begin{array}{l}-.000 \\
(.039)\end{array}$ \\
\hline Number of directors & $\begin{array}{c}.010 * * * \\
(.003)\end{array}$ & $\begin{array}{l}.007 * * \\
(.003)\end{array}$ & $\begin{array}{l}.005^{*} \\
(.003)\end{array}$ & $\begin{array}{l}-.000 \\
(.003)\end{array}$ & $\begin{array}{l}-.003 \\
(.003)\end{array}$ & $\begin{array}{l}-.005 \\
(.004)\end{array}$ \\
\hline Executive experience & $\begin{array}{l}.001 \\
(.004)\end{array}$ & $\begin{array}{l}.001 \\
(.004)\end{array}$ & $\begin{array}{l}.001 \\
(.003)\end{array}$ & $\begin{array}{l}.005 \\
(.003)\end{array}$ & $\begin{array}{l}.005 \\
(.003)\end{array}$ & $\begin{array}{l}.008 \\
(.005)\end{array}$ \\
\hline MA/MBA & $\begin{array}{l}-.056 \\
(.067)\end{array}$ & $\begin{array}{l}-.034 \\
(.071)\end{array}$ & $\begin{array}{l}-.064 \\
(.52)\end{array}$ & $\begin{array}{l}-.011 \\
(.049)\end{array}$ & $\begin{array}{l}-.011 \\
(.047)\end{array}$ & $\begin{array}{l}-.018 \\
(.062)\end{array}$ \\
\hline Between CEOs & $\begin{array}{l}.066^{* *} \\
(.030)\end{array}$ & $\begin{array}{l}.071 * * \\
(.031)\end{array}$ & $\begin{array}{l}.052 * * \\
(.022)\end{array}$ & $\begin{array}{l}-.029 \\
(.027)\end{array}$ & $\begin{array}{l}-.033 \\
(.025)\end{array}$ & $\begin{array}{l}-.042 \\
(.033)\end{array}$ \\
\hline Dummy supervision & $\begin{array}{l}-.008 \\
(.036)\end{array}$ & $\begin{array}{l}.017 \\
(.034)\end{array}$ & $\begin{array}{l}.005 \\
(.024)\end{array}$ & $\begin{array}{l}-.007 \\
(.022)\end{array}$ & $\begin{array}{c}.035 \\
(.025)\end{array}$ & $\begin{array}{c}-.032 \\
(.031)\end{array}$ \\
\hline Firm and year dummies & Yes & Yes & Yes & Yes & Yes & Yes \\
\hline Topic-subject dummies & Yes & Yes & Yes & Yes & Yes & Yes \\
\hline Number of observations & 1313 & 1313 & 1313 & 1313 & 1313 & 1313 \\
\hline F probability & .000 & .001 & .000 & .000 & .000 & .000 \\
\hline R-squared & .052 & .056 & .058 & .062 & .064 & .068 \\
\hline
\end{tabular}


Table 9

\section{Gender Composition and CEO Turnover}

This table reports OLS regressions analyzing a panel data set of the universe of the 34 GBCs, for the years 19972009. The dependent variable is a binary variable that equals one if the serving CEO finished serving in this position. The primary independent variables are the fraction of women directors appointed to each board, that latter dummy times ROE, a dummy that equals one if three women were appointed to the board, that latter dummy times ROE, a dummy that equals one if three men were appointed to the board, and that latter dummy times ROE. In addition, the regressions controls for the ROE, the fraction of outside directors, the number of directors, the tenure of the CEO, and a dummy that equals one if the CEO was a woman. Year and firm dummies are included as specified. For each variable, the first line reports the coefficient and the second line reports (in round parentheses) clustered errors on firm level. $* * * * *, *$, indicate significance at the $0.01,0.05$, and 0.10 level, respectively.

\begin{tabular}{|c|c|c|c|c|}
\hline \multirow[b]{3}{*}{$\begin{array}{l}\text { Fraction of women directors } \\
\text { appointed }\end{array}$} & \multicolumn{4}{|c|}{ Dependent variable: CEO turnover } \\
\hline & (1) & (2) & (3) & (4) \\
\hline & $\begin{array}{c}.186 * * * \\
(.027)\end{array}$ & $\begin{array}{c}-.447 * * * \\
(.069)\end{array}$ & & \\
\hline Fraction of women*ROE & $\begin{array}{l}-.338^{*} \\
(.000)\end{array}$ & $\begin{array}{c}3.080 * * \\
(.785)\end{array}$ & & \\
\hline $\begin{array}{l}\text { Square of fraction of women } \\
\text { directors }\end{array}$ & & $\begin{array}{c}.895^{* * * *} \\
(.056)\end{array}$ & & \\
\hline $\begin{array}{l}\text { Square of fraction of } \\
\text { women*ROE }\end{array}$ & & $\begin{array}{l}-5.450 * * \\
(.161)\end{array}$ & & \\
\hline $\begin{array}{l}\text { Three or more women } \\
\text { appointed }\end{array}$ & & & $\begin{array}{c}.096 * * * \\
(.012)\end{array}$ & $\begin{array}{c}.059 * * * \\
(.005)\end{array}$ \\
\hline $\begin{array}{l}\text { Three or more women } \\
\text { appointed*ROE }\end{array}$ & & & $\begin{array}{c}-.266^{* *} \\
(.090)\end{array}$ & $\begin{array}{c}-.270 * * * \\
(.007)\end{array}$ \\
\hline $\begin{array}{l}\text { Three or more men } \\
\text { appointed }\end{array}$ & & & $\begin{array}{c}-.030 * * \\
(.008)\end{array}$ & $\begin{array}{l}-.063 * \\
(.020)\end{array}$ \\
\hline $\begin{array}{l}\text { Three or more men } \\
\text { appointed*ROE }\end{array}$ & & & $\begin{array}{c}-.048 * * * \\
(.006)\end{array}$ & $\begin{array}{l}.105 \\
(.141)\end{array}$ \\
\hline ROE & $\begin{array}{l}-.015 \\
(.071)\end{array}$ & $\begin{array}{l}-.489 * \\
(.161)\end{array}$ & $\begin{array}{l}-.042 \\
(.022)\end{array}$ & $\begin{array}{l}-.109 \\
(.166)\end{array}$ \\
\hline Fraction of outsiders & $\begin{array}{c}-.198 * * * \\
(.021)\end{array}$ & $\begin{array}{c}-.173 * * * \\
\quad(.020)\end{array}$ & $\begin{array}{l}-.196^{*} \\
(.065)\end{array}$ & $\begin{array}{c}-.177 * * * \\
(.007)\end{array}$ \\
\hline Number of directors & $\begin{array}{l}.002 \\
(.004)\end{array}$ & $\begin{array}{l}.004 \\
(.004)\end{array}$ & $\begin{array}{l}.001 \\
(.002)\end{array}$ & $\begin{array}{l}.001 \\
(.002)\end{array}$ \\
\hline CEO tenure & $\begin{array}{c}.137 * * * \\
(.013)\end{array}$ & $\begin{array}{c}.137 * * * \\
(.012)\end{array}$ & $\begin{array}{l}.149 * * * \\
(.010)\end{array}$ & $\begin{array}{c}.137 * * * \\
(.013)\end{array}$ \\
\hline CEO woman & $\begin{array}{c}-.144 * * \\
(.040)\end{array}$ & $\begin{array}{c}-.136^{* *} \\
(.037)\end{array}$ & $\begin{array}{l}-.121 \\
(.084)\end{array}$ & $\begin{array}{l}-.129 * \\
(.042)\end{array}$ \\
\hline Number of observations & 285 & 285 & 289 & 289 \\
\hline Firm and year dummies & Yes & Yes & No & Yes \\
\hline F probability & .000 & .000 & .000 & .000 \\
\hline R-squared & .674 & .679 & .539 & .675 \\
\hline
\end{tabular}


Table 10

\section{Gender Composition and Board Activeness in the Absence of a CEO}

This table reports OLS regressions analyzing the issues discussed at board- and/or board-committee meetings by the 11 GBC boards examined. The dependent variable is a binary variable that equals one if the board either requested to receive further information or an update, or took an initiative (e.g., suggested which action should be taken). The primary independent variables are the fraction of attending women directors and its square, interaction variables for the latter two variables with a dummy documenting if this was a "between CEOs" period (i.e., the board was in the process of replacing a CEO), a dummy which equals one when at least three women directors were in attendance, a dummy which equals one when at least three men directors were in attendance, and interaction variables for the latter two variables with a dummy documenting if this was a "between CEOs" period. In addition, the regressions control for the fraction of attending outside directors, the total number of attending directors, the average number of years of executive experience of the attending directors, the fraction of attending directors with an MA/MBA, a dummy that equals one if the issue discussed was one of supervisory nature as described in Section 3.3.f, and a dummy that equals one if the issue was discussed at a board meeting as opposed to a board-committee meeting (not all these variables are reported). Regression 3 includes only observations concerning meetings which were attended by at least 6 directors. For each variable, the first line reports the coefficient and the second line reports (in round parentheses) the clustered errors at meeting level. $* * *, * *, *$, indicate significance at the $0.01,0.05$, and the 0.10 level, respectively.

\begin{tabular}{|c|c|c|c|}
\hline \multirow[b]{3}{*}{$\begin{array}{l}\text { Fraction of women directors in } \\
\text { attendance }\end{array}$} & \multicolumn{3}{|c|}{ Dependent variable: action taken } \\
\hline & (1) & (2) & (3) \\
\hline & $\begin{array}{l}-.033 \\
(.154)\end{array}$ & & \\
\hline $\begin{array}{l}\text { Fraction of women directors in } \\
\text { attendance } * \text { between CEOs }\end{array}$ & $\begin{array}{l}-.188 \\
(.259)\end{array}$ & & \\
\hline $\begin{array}{l}\text { Square of fraction of women } \\
\text { directors in attendance }\end{array}$ & $\begin{array}{l}.129 \\
(.192)\end{array}$ & & \\
\hline $\begin{array}{l}\text { Square of fraction of women } \\
\text { directors } * \text { between CEOs }\end{array}$ & $\begin{array}{l}.077 \\
(.306)\end{array}$ & & \\
\hline $\begin{array}{l}\text { Three or more women directors in } \\
\text { attendance }\end{array}$ & & $\begin{array}{l}.076^{*} \\
(.040)\end{array}$ & $\begin{array}{l}.151 * * \\
(.000)\end{array}$ \\
\hline $\begin{array}{l}\text { Three or more women directors in } \\
\text { attendance* between CEOs }\end{array}$ & & $\begin{array}{l}.111 * * \\
(.050)\end{array}$ & \\
\hline $\begin{array}{l}\text { Three or more men directors in } \\
\text { attendance }\end{array}$ & & $\begin{array}{l}.024 \\
(.578)\end{array}$ & $\begin{array}{l}.015 \\
(.062)\end{array}$ \\
\hline $\begin{array}{l}\text { Three or more men directors in } \\
\text { attendance* between CEOs }\end{array}$ & & $\begin{array}{l}.159 * \\
(.093)\end{array}$ & \\
\hline Fraction of outsiders & $\begin{array}{l}-.072 * \\
(.036)\end{array}$ & $\begin{array}{l}-.005 \\
(.005)\end{array}$ & $\begin{array}{l}.013 \\
(.009)\end{array}$ \\
\hline Number of directors & $\begin{array}{l}.002 \\
(.003)\end{array}$ & $\begin{array}{l}.001 \\
(.007)\end{array}$ & $\begin{array}{l}-.012 \\
(.023)\end{array}$ \\
\hline Appointing firing an executive & $\begin{array}{l}.226 \\
(.218)\end{array}$ & $\begin{array}{l}-.133 \\
(.326)\end{array}$ & $\begin{array}{l}.339 * \\
(.204)\end{array}$ \\
\hline Between CEOs period & $\begin{array}{c}.082 \\
(.052)\end{array}$ & $\begin{array}{l}-.146 \\
(.106)\end{array}$ & \\
\hline Only gap periods included? & no & no & yes \\
\hline Number of observations & 2459 & 1313 & 464 \\
\hline Board and committees? & Board \& committees & Only board & Board \& committees \\
\hline Firm and year dummies & Yes & Yes & Yes \\
\hline F probability & .000 & .000 & .000 \\
\hline R-squared & .114 & .115 & .229 \\
\hline
\end{tabular}


Table 11

The Gender of Directors and the Actions They Take

The data analyzed apply only to the cases in which the boards of the eleven GBCs examined requested further information or an update and/or made an impact (and for which it is possible to identify a single director as the one taking the action $-69 \%$ of the actions). The data are analyzed via OLS regressions on the level of the individual director taking the action. The dependent binary variable equals one if the action taken by a director pertained to a supervisory issue as opposed to a managerial issue, as described in Section 3.3.f. The primary independent variable examined is a dummy that equals one in cases the director taking the action was a woman. In addition, the regressions control for the fraction of all women directors in attendance and its square, fraction of outsiders, number of directors in attendance, average number of years of executive experience of the director taking the actions, a dummy which equals one if the director taking the action had an MA or an MBA, a dummy which equals one if the company was in the process of replacing the CEO at the time the issue was discussed, and a dummy which equals one if the issue was discussed at a board meeting as opposed to a board-committee meeting. For each variable, the first line reports the coefficient and the second line reports (in round parentheses) the errors. ***, **, *, indicate significance at the $0.01,0.05$, and 0.10 level, respectively.

\begin{tabular}{|c|c|c|c|}
\hline & \multicolumn{3}{|c|}{ Dependent variable: action taken on supervisory issue } \\
\hline & (1) & (2) & (3) \\
\hline Action taken by woman & $\begin{array}{l}.208 * * * \\
(.048)\end{array}$ & $\begin{array}{l}.159 * * * \\
(.050)\end{array}$ & $\begin{array}{c}.408 * * * \\
(.126)\end{array}$ \\
\hline Fraction of women & $\begin{array}{l}.135 \\
(.088)\end{array}$ & $\begin{array}{l}.066 \\
(.083)\end{array}$ & $\begin{array}{l}.902 \\
(.565)\end{array}$ \\
\hline Fraction of outsiders & $\begin{array}{l}.257 * * \\
(.120)\end{array}$ & $\begin{array}{l}.199 \\
(.145)\end{array}$ & $\begin{array}{l}-.265 \\
(.093)\end{array}$ \\
\hline Number of directors & $\begin{array}{l}-.008 \\
(.015)\end{array}$ & $\begin{array}{l}-.012 \\
(.020)\end{array}$ & $\begin{array}{l}-.015 \\
(.038)\end{array}$ \\
\hline Executive experience & $\begin{array}{l}.000 \\
(.008)\end{array}$ & $\begin{array}{l}-.003 \\
(.007)\end{array}$ & $\begin{array}{l}-.098 \\
(.050)\end{array}$ \\
\hline MA/MBA & $\begin{array}{l}.216 \\
(.149)\end{array}$ & $\begin{array}{l}.226 \\
(.152)\end{array}$ & $\begin{array}{l}-.594 \\
(.518)\end{array}$ \\
\hline Between CEOs & $\begin{array}{l}.017 \\
(.085)\end{array}$ & $\begin{array}{l}.010 \\
(.106)\end{array}$ & $\begin{array}{l}-.002 \\
(.150)\end{array}$ \\
\hline $\begin{array}{l}\text { Was board-committee } \\
\text { meeting }\end{array}$ & $\begin{array}{c}-.183 * * \\
(.089)\end{array}$ & & \\
\hline Meetings examined & $\begin{array}{c}\text { Board \& } \\
\text { committees }\end{array}$ & Board & Committees \\
\hline Number of observations & 326 & 101 & 225 \\
\hline Firm and year dummies & Yes & Yes & Yes \\
\hline F probability & .000 & .000 & .000 \\
\hline R-squared & .192 & .197 & .260 \\
\hline
\end{tabular}


Table 12

\section{Gender Composition and Length of Meetings}

The data analyzed applies to the 402 board and board-committee meetings held by the eleven GBCs examined. The dependent variable in the OLS regressions is the number of pages of minutes. The primary independent variable examined is the fraction of women directors in attendance. In addition, the specifications include the following control variables: the fraction of outsiders, number of directors in attendance, the average number of years of executive experience of the directors, the average percentage of directors with an MA/MBA, a dummy that equals one if the firm was in the process of replacing the CEO at the time the issue was discussed, and a dummy that equals one if the issue was discussed at a board meeting as opposed to a board meeting. For each variable, the first line reports the coefficient and the second line reports (in round parentheses) the robust errors. ***, **, *, indicate significance at the $0.01,0.05$, and 0.10 level, respectively.

\begin{tabular}{|c|c|c|c|c|}
\hline & \multicolumn{4}{|c|}{ dependent variable: number of pages of minutes } \\
\hline & \multicolumn{2}{|c|}{ board-committees } & \multicolumn{2}{|c|}{ board meetings } \\
\hline & (1) & (1) & (3) & (4) \\
\hline fraction of women directors & $\begin{array}{c}4.984 * * * \\
(1.698)\end{array}$ & $\begin{array}{l}7.491 * * \\
(3.457)\end{array}$ & $\begin{array}{c}.762 \\
(6.277)\end{array}$ & $\begin{array}{c}25.956 \\
(20.667)\end{array}$ \\
\hline $\begin{array}{l}\text { square of fraction of women } \\
\text { directors }\end{array}$ & & $\begin{array}{l}-2.803 \\
(3.617)\end{array}$ & & $\begin{array}{c}30.227 \\
(19.585)\end{array}$ \\
\hline fraction of outsiders & $\begin{array}{l}-2.025 \\
(1.785)\end{array}$ & $\begin{array}{l}-1.990 \\
(1.765)\end{array}$ & $\begin{array}{l}-2.574 \\
(5.903)\end{array}$ & $\begin{array}{c}-1.374 \\
(5.757)\end{array}$ \\
\hline number of directors & $\begin{array}{l}-.096 \\
(.313)\end{array}$ & $\begin{array}{l}-.1707 \\
(.338)\end{array}$ & $\begin{array}{l}.700 \\
(.593)\end{array}$ & $\begin{array}{l}.830 \\
(.605)\end{array}$ \\
\hline average executive experience & $\begin{array}{l}.368 * * \\
(.106)\end{array}$ & $\begin{array}{c}.367 * * * \\
(.107)\end{array}$ & $\begin{array}{l}1.192 \\
(.725)\end{array}$ & $\begin{array}{l}1.167 \\
(.734)\end{array}$ \\
\hline average MA & $\begin{array}{l}.351 \\
(1.540)\end{array}$ & $\begin{array}{l}.425 \\
(1.543)\end{array}$ & $\begin{array}{c}-5.700 \\
(4.902)\end{array}$ & $\begin{array}{l}-4.298 \\
(3.888)\end{array}$ \\
\hline between CEOs & $\begin{array}{l}-1.322 \\
(1.182)\end{array}$ & $\begin{array}{l}-1.290 \\
(1.172)\end{array}$ & $\begin{array}{l}-7.165^{* * *} \\
(2.369)\end{array}$ & $\begin{array}{l}-6.406 \\
(2.320)\end{array}$ \\
\hline firm and year dummies & Yes & Yes & Yes & Yes \\
\hline number of observations & 247 & 247 & 155 & 155 \\
\hline F probability & .000 & .000 & .000 & .000 \\
\hline R-squared & .638 & .638 & .574 & .580 \\
\hline
\end{tabular}




\section{Appendix A: Additional Information on GBCs}

Israel's 1999 "Corporation Law", which applies to all corporations in Israel (including government owned firms), and its 1975 "Government Companies Law" (GCL), which applies only to government-owned firms, detail the duties incumbent upon their boards. Both laws stress that the board must determine the company's policy and monitor the CEO. Concerning "business companies", which are the firms examined in this study, the Government Companies Law explicitly requires that "the firm operate according to business considerations just as firms with no government shareholder do" (authors' translation).

Furthermore, the GCL specifies additional tasks for which the board is responsible, which include determining the company's budget, discussing the financial reports, determining the long-term strategic plan, as well as choosing, appointing, and monitoring the CEO. The GCL also states that the CEO is not permitted to serve as the chairman or as a director of the firm of which he is the CEO. However, in our sample the CEO is present in virtually all meetings of the board and its committees. ${ }^{35}$

The bylaws of each GBC generally require that the board be made up of eight to twelve directors, with seven to ten serving directors being most common. The bylaws of each of the companies also specify which ministers appoint the directors of the company; in most cases it is the Minister of Finance and one additional relevant minister. ${ }^{36}$ In certain cases, the bylaws state that some of the directors must be employees of the ministries, and/or representatives of the company's employees, but in none of the companies can more than two of the latter sit on a board. The 1975 "Government Companies Law" imposes restrictions on nominating politicians to GBC boards, and the nomination committee strictly enforces these restrictions. Hence, although the directors nominated must be somehow connected to the ministers, virtually no politicians were nominated to the firms examined.

GBC directors have the same fiduciary duties as directors serving on public and private Israeli companies. Israel's 1999 "Corporation Law" specifies these duties: "An office holder shall owe a fiduciary duty to the company, shall act in good faith and for the benefit of the company" (paragraph 254 (a)). Israeli law is based on the Common Law, and therefore is very similar to comparable American law. Lawsuits against officers and directors of both public and private companies are less common In Israel than in the United States. All directors in our sample have Directors and Officer's Liability Insurance, which provides them similar coverage to that provided to directors of comparable non-governmental firms. The only compensation given to GBC directors is a fixed compensation for each meeting they attend, which ranges between $\$ 185$ and $\$ 350$ per meeting, depending on the company's size. ${ }^{37}$

\footnotetext{
${ }^{35}$ All GBCs have finance and audit board-committees. In addition, most GBCs have approximately two to three additional board-committees.

${ }^{36}$ The GCL requires that in companies in which the government holds more than half the votes in the general stockholders' meetings, directors must be at least twenty-five years old, be residents of Israel, and either have degrees in business, economics, law, accounting, engineering, public service, or any other field relevant to the firm, or have at least five years of relevant experience or experience in a senior management position. The requirements regarding the chairman are even stricter.

${ }^{37}$ Although this financial compensation is not high, there are many candidates interested in being directors of GBCs, since such positions provide status, the expansion of one's professional network, and also enable the development of an expertise in demand in the better-paying private sector. In small and medium companies, the chairman is not employed on a full-time basis, and his compensation is based on the number of meetings he actually attends. In large companies, the chairman is employed on a full-time basis, and accordingly receives (only) a monthly salary.
} 


\section{Appendix B: Complete Coding Guidelines}

\section{B.1. Complete coding guidelines}

The following coding guidelines were defined in coding the data:

1. General information. For each issue discussed, the coding included the name of the company, date of meeting, type of meeting (board or a specific board-committee), whether the issue was merely presented as an update or alternatively culminated in a decision made by the board, the number of lines in the minutes documenting the issue discussed, and the total number of pages of minutes of the complete meeting at which the issue was discussed.

2. Aggregate topic-subjects. Each topic discussed or decision made in a board meeting or boardcommittee meeting was coded under one of the following five aggregate topic-subjects: audit and contracting, business issues, financial issues, formal issues, and personnel and benefits. Each of these aggregate topic-subjects includes the following 23 topic subjects (defined in Section A.2 of this appendix):

a. Audit and contracting: audit issues, contracting or purchases, legal, and ratification of audit committee.

b. Business issues: business issues, business projects, cross-firm issues, ongoing general issues, ratification of operational committee, regulation and government, and strategic issues.

c. Financial issues: budget, financial reports, investment or finance, and ratification of financial committee.

d. Formal issues: appointments of members, approving past minutes of meetings, choosing a chairman for the meeting, and formal issues.

e. Personnel and benefits: appointing or firing an executive, organizational change, personnel and benefits, and ratification of human resources committee.

3. Supervision. All topic-subjects were divided according to whether they were of supervisory or managerial nature. Supervisory topic-subjects were defined as appointment of members, approving minutes of earlier meetings, audit issues, choosing a chairman for the meeting, contracting or purchases, financial reports, formal issues, legal issues, personnel and benefits, ratification of audit committee, ratification of human resources committee, ratification of operational committee, ratification of financial committee, and regulation and government. Managerial topic-subjects were defined as appointing or firing an executive, budget, business issues, business projects, cross-firm issues, investment or finance, ongoing general issues, organizational change, and strategic issues.

4. Presentation of alternatives. These are cases in which the board was presented with at least two alternatives, including cases in which the CEO or management made its own preference clear.

5. Further updates. These are cases in which the board requested to receive further information or an update on the subject discussed. In cases in which concerning a single topic-subject the board requested more than one update or further information, this was coded as one request.

6. Taking an initiative. When a board actively did something that was meant to improve the company, according to its own understanding, this was coded as either "minor initiative" or as "major initiative". Minor initiative indicates that the board slightly modified the original proposal. For examples: the board approved a lease it was asked to approve, yet decided to introduce a few revisions of details; the board requested that some moderate action be taken, for instance, that the CEO write a letter to the regulator about an issue discussed at the board meeting; or the board decided to form a committee or appoint a director to handle a certain issue, but when this decision was made it is too early to know whether any action was indeed taken. ${ }^{38}$ Major initiative indicates that the board took an active part in defining the steps or actions that should be taken, or delved into an issue it actively requested to discuss. For example: a board requested to examine the company's policy concerning perks (e.g.,

\footnotetext{
${ }^{38}$ If the minutes of subsequent meetings documented that the board did take a major initiative, it was categorized accordingly for that subsequent meeting.
} 
which employees were eligible to be driven to work, at what times, and under what circumstances), discussed the policy concerning that perk quite thoroughly, and finally, formulated and adopted a new alternative policy; or a board actively sought, both within the boardroom and elsewhere, to change the regulation imposed on the firm. ${ }^{39}$

7. Decision in line with CEO. For each decision made by the board, the decision was coded as either in line, partially in line, or not in line with the CEO's or management's proposal. ${ }^{40}$

8. Dissension. These are cases in which a decision was made, and one or more of the directors did not vote as the others (either opposing them or abstaining).

9. Size of board and board composition. For each meeting, the total number of attending directors was coded, along with the number of attending women directors, directors from ethnic minority members (Arabs), and outside directors. ${ }^{41}$

10. No serving CEO. These are cases in which the firm had no CEO at the time the board or boardcommittee meeting was held.

11. Consistency. To assure consistent standards all coding was executed by a single person (one of us) ${ }^{42}$ who reviewed the coding several times.

\section{B.2. List of topic-subjects}

Each topic discussed or decision made in a board or board-committee meeting was coded under one of the following 23 topic-subjects.

i. Appointing or firing an executive - executives include the CEO, his deputies, and the auditor.

ii. Appointment of members - to board-committees or boards of subsidiary firms.

iii. Approving minutes of past meetings - formal approval of the minutes by the board.

iv. Audit - audit reports and audit issues regarding the firm.

v. Budget-updates, suggested changes, and projected budget.

vi. Business issues - a standard business issue. For instance, in the case of a bank, waiving part of a problematic debt.

vii. Business project - data regarding a specific project the firm or a subsidiary had undertaken or ad considered undertaking.

viii. Choosing a chairman for the meeting - for companies that do not have a permanent chairman and elect one for each board meeting.

ix. Contracting or purchases - contracts regarding purchasing raw materials, supplies, real estate, or services, for example, from advisers and external accountants. This category also includes problems that could arise within contractual relation.

\footnotetext{
${ }^{39}$ One could argue that this specific coding category is one with a soft definition. For this reason, great care was taken to assure that the coding be conducted according to consistent standards. After the coding was completed, apart from the general rechecking of all of the coding, the coding of this specific category was carefully reexamined throughout all minutes examined.

${ }^{40}$ In cases in which the chairman received a monthly salary and, accordingly, dedicated most of his time to the firm, it is generally evident from the minutes that in the boardroom his views were coordinated and aligned with those of the CEO. In these cases, the chairman usually complemented the CEO and vice versa. Accordingly, views of chairmen who receive monthly salaries were regarded and coded as identical to those of the CEO. In contrast, in firms in which the chairman was compensated only on a base of board and board-committee meetings he attended, his views were not always coordinated and aligned with those of the CEO and, therefore, he was regarded as a board member and his views were coded accordingly as views of the board.

${ }^{41}$ Inside directors were defined as government employees and firm employees.

${ }^{42}$ This was also due to the confidentiality of the minutes, which were made available to the authors with the proviso that virtually only they be allowed access to them.
} 
x. Cross-firm issues - an issue with across-the-firm implications (for example, proposed changes in the customer service or moving the offices to a new location), or the plans of a specific unit that have ramifications and implications for the firm at large.

xi. Financial reports - discussions regarding the financial reports and the assumptions upon which they rely.

xii. Formal issues - issues that must receive the formal approval of the board, such as granting the authority to sign a contract or financial reports or to represent the firm in a general meeting.

xiii. Investment or finance - issues regarding money invested, borrowed from banks or the government, or raised from institutional investors or the stock market, and also issues regarding the firm's floating stock.

xiv. Legal-legal issues, including insurance.

xv. Ongoing general issues - ongoing continuing issues in the life of the firm, including brief anecdotal updates on issues previously discussed by the board. Most board meetings commenced with such brief updates presented by the CEO or chairman. When distinct issues were discussed in detail, each was coded separately.

xvi. Organizational change - structural changes in the firm.

xvii. Personnel and benefits - employee benefits (e.g., receiving bonuses or leasing cars), behavioral problems among employees, changes in the total number of employees, general policies regarding employees, and a limited range of issues regarding compensation and benefits received by the directors.

xviii. Ratification of audit committee - a decision made by the audit board-committee that was only briefly presented to the board, to allow ratification of the decision.

xix. Ratification of financial committee - a decision made by the financial board-committee that was only briefly presented to the board, to allow ratification of the decision.

$\mathrm{xx}$. Ratification of human resources committee - a decision made by the human resource boardcommittee that was only briefly presented to the board, to allow ratification of the decision.

xxi. Ratification of operational committee - a decision made by the operational board-committee that was only briefly presented to the board, to allow ratification of the decision.

xxii. Regulation and government - relation with the government, whether as regulator, shareholder, or otherwise. Examples of issues included are fees determined by the regulator, dividends the government demanded, and privatization.

xxiii. Strategic issues - discussions pertaining to the strategic business plan of the firm, or at least of a major activity of the firm, for the following years. 


\section{Appendix C - Examples of Actions Taken}

This appendix illustrates the types of actions that were taken by the boards. Namely, the appendix documents all the actions that were taken and coded under one of the twenty-three topic subjects - the "budget" topic-subject. For the budget topic-subject, eighteen requests were made to receive further information or an update, and ten initiatives were taken. All these actions are specified bellow.

\section{Requests to receive further information or an update:}

The board requested to receive:

1. A sensitivity analysis examining how the budget would change if the Dollar - Israeli New Shekel exchange rate would increase or decrease.

2. Information on new business projects that have not been presented to the board, and the proposed budget for those business projects.

3. An analysis examining how the budget would be affected if the firm's projected revenue were to decrease by $5 \%$.

4. An analysis of how the valuation methods required by SOX (which the firms were required to implement gradually) affected the value of the firm's assets and those of its daughter companies.

5. An analysis of how purchasing raw materials in the spot market could affect the firm's budget.

6. The actual expenses of several projects, compared to those projected.

7. An analysis of the expenses incurred in order to maintain the vehicles owned and used by the company, and a parallel analysis as to what the company's expenses would be if it were instead to lease the vehicles it uses.

8. A report on the profitability of the different business sectors in which the firm operates.

9. A list of all the outside advisers providing services to the firm, the services they provide, and their cost.

10. An updated budget following the firing of some of the employees.

11. Information on how one of the major raw materials is purchased, and a proposal of alternatives that could possibly cut those expenses.

12. A report on a specific budget category that, in the previous year, the board had demanded be cut, and on the actual expenses in this budget category.

13. A more accurate long-term budget.

14. A new investment budget that would be cut by $10 \%$.

15. A legal opinion concerning the company's ability to use a designated budget category for other purposes.

16. A document that summarizes the exposures of the company following a change in regulation.

17. A quarterly update comparing the budget as initially planned to actual expenses.

18. Several alternatives to the proposed budget.

\section{Initiatives taken:}

1. Following the presentation of the revenue and expenses of one of the daughter firms, the board expressed its desire to consider seriously selling this daughter company. An additional discussion of this topic was scheduled.

2. Following receipt of a budget update, the boards requested that the firm change its policy not to include any "allowance for bad debt", and that it indeed make such an allowance.

3. To increase the limited cash flow of the company, the board suggested and decided that the company attempt to increase its suppliers' credit, and that it limit the number of miles employees are permitted to drive in the companies vehicles as well as the limits on cell phone bills that would be covered by the firm.

4. The board proposed and decided to hire an outside consultant who would map the firm's financial exposures, and recommend how to invest the firm's cash.

5. The board proposed and decided that the budget allocated to providing improved customer service be increased. 
6. The board made it clear that it expected the company to generate a minimal profit it had defined, and demanded the projected budget be revised accordingly.

7. The board requested that the CEO seek alternative suppliers. These alternative suppliers were expected to affect the short- and long-term budget.

8. The board initiated a meeting with the regulator, which was attended by the board and the management. In this meeting, the boards and management requested that the regulation be changed in a way that would increase the firm's income.

9. The board decided to make priorities as to which projects should receive increased budget, and at the next meeting, accordingly, it made changes in the proposed budget.

10. The board initiated a discussion on the times, intervals, and format in which it wishes to receive information concerning the budget. 


\section{Appendix D \\ Board Meetings on Days with and without Board-Committee Meetings}

This table compares board meetings that were held on days no board-committee meeting was held ("only board") to board meetings held on days on which at least one board-committee meeting was held ("board and committee"). Panel 1 breaks down the number of issues discussed categorized as important versus those categorized as being only of secondary importance. Important issues are defined as appointing or firing an executive, budget, business issues, business projects, cross-firm issues, financial reports, investment/ finance, organizational changes, personnel and benefits, regulation and government, and strategic issues. Issues of secondary importance include appointment of members, approving minutes of past meetings, audit, choosing a chairman for the meeting, contracting and purchases, formal issues, legal issues, ongoing general issues, ratification of audit committee, ratification of financial committee, ratification of HR committee, and ratification of operational committee. Column 1 in Panel 1 reports the average percentage of the number of issues boards discussed that were categorized as important (i.e., number of important issues/( number of important issues + number of issues of secondary importance)), while Column 2 reports the percentage of time boards spent discussing important issues. The time spent on each issue discussed is estimated based on the number of lines in the minutes that document each discussion. Column 3 reports the percentage of the number of supervisory issues boards discussed as opposed to managerial issues (see Table 11 for definitions), and Column 4 reports the percentage of time boards spent on supervisory issues. Panels 2 and 3 break down, on the aggregate topic-subject level, the topics discussed by boards depending on whether a board-committee took place on the same day (Panel 2), and depending on whether a dual critical mass (at least three directors of each gender) was in attendance. All panels report for each column t-statistics that examine whether the percentages pertaining to "only board" observations, as opposed to "board and committee" observations, are statistically different.

Panel 1

\begin{tabular}{lcccc}
\hline & $\begin{array}{c}\text { Number of } \\
\text { issues } \\
\text { Important }\end{array}$ & $\begin{array}{c}\text { Percent of } \\
\text { time } \\
\text { Important }\end{array}$ & $\begin{array}{c}\text { Number of } \\
\text { issues } \\
\text { Supervisory }\end{array}$ & $\begin{array}{c}\text { Percent of } \\
\text { time } \\
\text { Supervisory }\end{array}$ \\
\hline Only board & $51.6 \%$ & $64.5 \%$ & $64.0 \%$ & $58.3 \%$ \\
Board and committee & $40.6 \%$ & $57.5 \%$ & $62.5 \%$ & $53.0 \%$ \\
t-statistic (two sided) & 0.568 & 0.186 & 0.692 & 0.295 \\
\hline
\end{tabular}

Panel 2

\begin{tabular}{lcccccr}
\hline & \multicolumn{5}{c}{ Percentage of issues discussed broken down by aggregate topic-subject level } \\
& $\begin{array}{c}\text { Business } \\
\text { issue }\end{array}$ & $\begin{array}{c}\text { Financial } \\
\text { issues }\end{array}$ & $\begin{array}{c}\text { Formal } \\
\text { issues }\end{array}$ & $\begin{array}{c}\text { Personnel \& } \\
\text { benefits }\end{array}$ & $\begin{array}{c}\text { Audit \& } \\
\text { contracting }\end{array}$ & Total \\
\hline Only board & $11.9 \%$ & $36.6 \%$ & $18.4 \%$ & $5.0 \%$ & $28.2 \%$ & $100 \%$ \\
Board and committee & $10.3 \%$ & $27.6 \%$ & $25.4 \%$ & $3.6 \%$ & $33.1 \%$ & $100 \%$ \\
t-statistic (two sided) & 0.614 & 0.342 & 0.655 & 0.134 & 0.930 & \\
\hline
\end{tabular}

Panel 3

\begin{tabular}{lcccccr}
\hline & \multicolumn{5}{c}{ Percentage of issues discussed broken down by aggregate topic-subject level } \\
& $\begin{array}{c}\text { Business } \\
\text { issue }\end{array}$ & $\begin{array}{c}\text { Financial } \\
\text { issues }\end{array}$ & $\begin{array}{c}\text { Formal } \\
\text { issues }\end{array}$ & $\begin{array}{c}\text { Personnel \& } \\
\text { benefits }\end{array}$ & $\begin{array}{c}\text { Audit \& } \\
\text { contracting }\end{array}$ & Total \\
\hline Dual critical mass & $11.8 \%$ & $29.8 \%$ & $18.6 \%$ & $17.9 \%$ & $21.9 \%$ & $100 \%$ \\
No dual critical mass & $11.8 \%$ & $28.9 \%$ & $16.1 \%$ & $20.9 \%$ & $22.1 \%$ & $100 \%$ \\
t-statistic (two sided) & 0.982 & 0.801 & 0.459 & 0.290 & 0.963 & \\
\hline
\end{tabular}

